\title{
The effects of green consumer empowerment in advertising on corporate evaluations and purchase intention: the case of organic food
}

\author{
Xisi Yang $^{1}$ (D) Anja Weber ${ }^{1} \cdot$ Anna-Katharina Grimm $^{1}$
}

Received: 4 May 2020 / Accepted: 9 September 2021 / Published online: 5 October 2021

(C) The Author(s) 2021

\begin{abstract}
This research aims to investigate the potential of consumer empowerment, the activation of consumers' perceived power over companies, to achieve improved advertising effects for organic food compared to only communicating ecological benefits (classical green appeals). Two online experiments were conducted to analyze the ad effectiveness for consumers' responses including their evaluations of the company and purchase intentions $\left(\mathrm{n}_{\text {Study } 1}=294 ; \mathrm{n}_{\text {Study2 }}=457\right)$. Results indicate that green empowerment ads reach overall better performance to increase people's perceived customer orientation and purchase intentions compared to green appeals, while similar effects are identified for perceived corporate environmental responsibility. Empowerment tactics are especially effective when consumers perceive the supplier to be a larger, high-resource company compared to a smaller, low-resource one. The significant effects of perceived corporate resources also indicates that smaller companies should use differentiated ad strategies depending on if they intend to enhance consumers' purchase intentions or their environmental reputation.
\end{abstract}

Keywords Green advertisement - Consumer empowerment - Customer orientation · Organic food

Mathematics Subject Classification 62P25 (social science) · 62P15 (psychology)

Xisi Yang

xisi.yang@hhl.de

Anja Weber

a.weber@hhl.de

Anna-Katharina Grimm

anna.grimm@uni-jena.de

1 Chair of Marketing Management and Sustainability, HHL Leipzig Graduate School of Management, Jahnallee 59, 04109 Leipzig, Germany 


\section{Introduction}

Preventing further ecological damages caused by intense conventional agricultural production such as soil erosions and groundwater pollution, requires stronger support from markets or a vital shift in consumption (e.g., Gomiero et al. 2011; Ma et al. 2019). Consumers' willingness to pay a price premium for socially and environmentally responsible products is evidenced in extant research (e.g., see a meta-analysis by Tully and Winer 2014). Besides these positive attitudes, previous research also shows that companies need to be cautious with unexpected adverse effects when advertising their products as environmentfriendly. For instance, consumers show more negative product evaluations and lower buying intentions if they consider the product's environmental benefit to be intended by the company because consumers assume that the company spends more resources on environmental protection instead of product quality (Newman et al. 2014). Further, Auger et al. (2008) showed that consumers' purchase intentions significantly drop when they perceive weak functional attributes, even though products demonstrate strong social attributes. Thus, consumers still seem to consider other criteria to be more important for their purchase than social or environmental sustainability. The question arises how companies can achieve positive effects of communicating their environmental friendliness in advertisements on consumer responses while not undermining other relevant criteria or even provoking adverse effects.

Extant research has broadly investigated the effects of green appeals, a form of messages that emphasize a product's or a behavior's positive ecological impact to increase consumers' pro-environmental intentions and behaviors (e.g., Atkinson and Rosenthal 2014; Chang et al. 2015). For example, Chang et al. (2015) tested messages referring to saved natural resources (barrels of petroleum, tons of water, and numbers of trees) through using electricity-based hybrid cars. However, a crucial weakness of green appeals is that their effectiveness depends on a person's level of environmental involvement (e.g., Cheng et al. 2020), such that these appeals may have little effect on less environmentally involved or committed individuals. Moreover, appeals to the ecological impact of personal purchase can leave the impression that the consumer alone is obligated to take responsibility for environmental protection, which is inconsistent with consumers' beliefs that both consumers' and companies' actions can make a difference (Lenzen et al. 2007; Yang and Weber 2019). Further research is required to target existing weaknesses of green appeals and to deliver more effective communication concepts to optimize advertisements for sustainable products. We aim to achieve this with this paper.

Although people's overall support for sustainability is documented by large protests such as the climate strike, this support is not equivalently reflected in their purchase behaviors as shown by small market shares of sustainable products (e.g., Carrington et al. 2014; EU 2019). To significantly enhance sustainable purchase in today's consumer-led markets, it might be necessary for companies to communicate more explicitly that the decisive choice lies with the buyers. 
Whether consumers actually request and buy sustainably produced products determines companies' adaptations. In line with the concept of consumers' market power (Kotler, 2011; Rezabakhsh et al. 2006; Shaw et al. 2006), we assume that consumers' more frequent choices of sustainable instead of conventional products decide whether (more) companies will increase the production of sustainable products and reduce that of conventional products. When a company signals a sense of consumers' control over its decisions, we call this consumer empowerment (Wright et al. 2006). In product marketing, extant research has mostly applied the empowerment concept for the joint development of products (e.g., Füller et al. 2009). For instance, Fuchs et al. (2010) focused on empowered consumers who participated in the product selection process (i.e., selecting products which will be sold to the broader market). However, this form of participation will only be possible for a small group of highly involved consumers who are willing to invest extra time and efforts. In contrast, we have designed and tested an empowerment approach in the sense of highlighting individuals' freedom to choose the type of products they like and, in this way, to apply their purchase power to enable producers to make decisions that prioritize consumer needs and finally to increase overall consumer welfare (Denegri-Knott et al. 2006). This seems to be an approach of consumer empowerment that bases on the purchase decision itself as a resource but does not necessarily require an activation of additional resources such as time and efforts. Thus, we expect our concept to be able to target a broader consumer group. Akhavannasab et al. (2018) called for more experimental research on consumers' responses to companies' empowerment tactics, such as through activating consumers' perceived power over companies. We investigate whether verbal priming in advertisements can contribute to increase consumers' perceived power over companies. Further, extant research has only investigated consumer empowerment in relation with conventional but not sustainable products (e.g., Füller et al. 2009). Taking these research gaps into account, we develop and test a green empowerment ad that communicates consumer choices as the major driver of companies' decisions to offer more environment-friendly products and to become more sustainable.

In the present research, we focus on organic food products for several reasons. First, food consumption is responsible for a substantial share of households' environmental impact (Ivanova et al. 2016; Poore and Nemecek 2018). Inducing a change in food consumption behavior could therefore help to substantially reduce carbon dioxide emissions and to mitigate climate change. Second, organic food is often associated with a significant price premium (Galarraga and Markandya 2004), which makes consumers' adoption more difficult compared to buying those sustainable products that bring a financial benefit (e.g., the usage of energy-efficient appliances also saves electricity costs). Third, organic food purchases are, to a large extent, motivated by personal benefits such as healthiness and taste (Prada et al. 2017; Rana and Paul 2017). Thus, green appeals, which only emphasize environmental benefits, might backfire. Fourth, food is a low involvement product (Atkinson and Rosenthal 2014; Thøgersen et al. 2012) and grocery shopping is mainly driven by habitual patterns (Ersche et al. 2017). Thus, when buying food products, consumers might be less likely to consciously make new evaluations of product features and suppliers, 
compared to when buying more durable and expensive high-involvement products (e.g., Nkwocha et al. 2005). Hence, establishing new considerations such as green empowerment (emphasizing consumers' power to foster producers' sustainability) could be especially challenging for organic food products. To tackle the challenges associated with the organic food domain and the weaknesses of green appeals as previously discussed, we chose organic food as a product category to test the effects of a green empowerment ad.

In recent years, researchers, industries and the public sector have used different approaches to encourage consumers' sustainable choices. For example, the City of Melbourne in partnership with the organization "Sustainable Table" published a recommendation guide called "We Need to Talk about Food", which frames their aim as "empower[ing] people to use their shopping dollar to vote for a food system that is fair, humane, healthy and good for the environment." (CoM 2019; see Appendix Fig. 4) Similar framing has been also used by a number of bloggers and activists: Greenpeace chose the slogan "Have a break? Give orangutans a break." in a video clip to protest against Nestlé's purchase of palm oil produced from destroyed rainforest (CNN, 2010). While the clip had raised public pressure on Nestlé, the provocative message also empowered consumers to make active decisions against specific products. This kind of empowerment has not been investigated as a communication concept. Far less has it been analyzed in relation with specific products in a purchase context, neither from the angle of how consumers evaluate a company that applies it. When applying the empowerment concept on environment-friendly products, it is crucial to find out whether consumers would credit or perceive a company's environmental responsibility against the background of existing greenwashing activities in current markets (Nyilasy et al. 2014). Further, emphasizing a company's willingness to adapt to customer needs is expected to increase consumers' perceived customer orientation (Brady and Cronin 2001). Moreover, depending on the company's size and resource availability (e.g., technological know-how, financial capital), consumers might have different expectations about the companies' ability to react to consumers' demand and to implement more environment-friendly technologies in the production (Wu 2017). Extant research has not considered the effects of perceived corporate resources on ad effectiveness, which we address in this paper.

To sum up, the objectives of this research are: (a) to conceptualize and empirically investigate green consumer empowerment as an advertising concept for organic food products, (b) to evidence the hypothesized conceptual differences between green empowerment ads and other ad types (green appeals, non-green empowerment ads) as well as the effectiveness improvement, (c) to analyze the ad effectiveness to affect corporate evaluations (customer orientation, corporate environmental responsibility) and purchase intentions, and (d) to conceptualize perceived corporate resources and to analyze its moderating effect for ad effectiveness, i.e. perceived CER. Study 1 serves to tackle the objectives (a), (b), and (c). Study 2 validates these results by conducting a replication and additionally investigates non-green empowerment ads and tackles objective (d).

In terms of operationalization, two empirical studies with a between-subject experimental design explore the effects of empowerment elements in ads for green products on consumers' corporate evaluations and, therefore, intentions to buy 
organic food. Study 1 analyzes the effects of a green empowerment ad on consumers' perceptions of corporate environmental responsibility and customer orientation as well as their intention to buy organic food, compared to a green appeal and a control group. Based on that, Study 2 tests the moderating influence of perceived corporate resources in a 3 (ad type: green empowerment vs. non-green empowerment vs. green appeal vs. control) $\times 3$ (corporate resources: high vs. low vs. control) setting. Study 2 additionally includes a "non-green empowerment" ad, which stresses consumers' purchase power over companies in a more general way (without the goal to increase green production) as a reference group.

The remainder of this paper is organized as follows: Sect. 2 provides a theoretical foundation of consumer empowerment in sustainable consumption and in relation to corporate evaluations (customer orientation, CER) and the perception of corporate resources. Section 3 (4) reports research methods and results of Study 1 (Study 2). Section 5 discusses the hypothesized effects based on previous literature and study results but also delivers theoretical and practical implications while pointing out limitations with an outlook for future research.

\section{Theoretical foundation and hypotheses}

\subsection{The role of consumer empowerment in sustainable consumption}

Power is defined as the capacity to control one's own (but also others') resources or outcomes (Keltner et al. 2003). Empowerment involves the loss of power by one party to another or the acquisition of power by one party over another (Lincoln et al. 2002). Based on that, a traditional view of consumer empowerment suggests a shift in power from producers to consumers (Wright et al. 2006), more specifically, the company's signaling or implementing the process of transferring control over specific corporate activities or resources to the consumer (Fuchs et al. 2010). Modern consumers are portrayed as "having an unprecedented power to choose, to customize the goods and services that they want, to avoid the undesired ones" (Wright et al. 2006 , p. 1014). Therefore, we define empowerment in its traditional sense as the power to exercise choice.

An empowered person is more optimistic and active than one who feels less powerful (Anderson and Galinsky 2006). Moreover, a "can-do" state of mind is achieved through empowerment, and it fosters behavioral actions (Pierce et al. 2003). An individual who feels more powerful is likely to make a buying decision or to buy a higher quantity (Galinsky et al. 2003; Rucker et al. 2012). For instance, when consumers are invited to select which products are marketed, the product demand increases (Fuchs et al. 2010). Similar effects occur when consumers are actively involved in product co-creation processes (Fuchs and Schreier 2010). In the food domain, Jacobsen et al. (2020) demonstrated that empowerment through co-creating new food products has a positive effect on consumers' trust in the company if the information is communicated by peer co-creators. To date, however, little research addresses how consumers can be put into this empowered state during a purchase 
decision in an easily implementable and time-efficient way. Advertising messages could be a useful tool for this.

Most sustainable product marketing employs classic green appeals, which are aimed at making consumers aware of their personal impact on the environmental state. Green appeals can refer, for instance, to the positive consequences of engaging in an environment-friendly behavior or to the negative consequences of not doing so (gain- vs. loss-framed messages; e.g., White et al. 2011). However, in both cases, these appeals only direct consumers' attention to their impact on the environment (e.g., how they can reduce emissions or conserve natural resources; Ramirez et al. 2015), ignoring the impact that consumers can have on the companies that create the products. Apart from consumers' environmental impact directly related to the environment-friendly product purchased, consumer purchase choices can also shape the company's decisions on product offerings or production manners (generally or specifically with regard to environment-friendly operations; e.g., Buerke et al. 2017).

Therefore, as previously discussed, we propose a new form of advertising herein: A green empowerment ad emphasizes the decisive role of consumer choices for companies' decisions to offer more environment-friendly products and to operate more sustainably. Previously investigated green appeals highlight the individual's environmental impact, which could lead consumers perceiving a high level of environmental responsibility. In contrast, a green empowerment ad emphasizes consumers' free choices for specific kinds of products to activate the perception of consumers' (purchase) power that can be exercised on companies to achieve a better environment. In light of the positive effects of consumer power (e.g., Anderson and Galinsky 2006; Fuchs et al. 2010; Rucker et al. 2012), green empowerment elements could improve corporate perceptions and also increase consumers' intention to buy organic foods.

Of course, empowering consumers via messages could also be applied without focusing on environmental aspects, only making consumers aware of their power over a company's offer. Such a non-green empowerment ad only stresses consumer choices while ignoring the sustainability of the product. Nevertheless, the perceived product sustainability can be an important driver for purchasing decisions, if the negative effects described can be counteracted (e.g. Nilssen et al. 2019). In this respect, we assume that addressing both customer orientation and sustainability could achieve two additive positive effects on consumers' purchase intentions in the organic food domain. So, depending on the product category, the green empowerment ad could be more promising than non-green empowerment ads or green appeals.

\subsection{The effect of green empowerment ad on corporate evaluations}

Most existing studies on green advertising focus on their effect on consumers' evaluations of the ad or the advertised product, such as consumer attitudes to the ad (Jiménez and Yang 2010), the credibility of the ad (Jäger and Weber 2020), or emotional responses (Amatulli et al. 2019) as antecedents of consumer behavior. In contrast, the effect of green advertising on corporate evaluations is examined 
less often, although consumers' responses are significantly determined by what they know about a company (see e.g., Mohr et al. 2001). The perception of a supplier's corporate social or environmental engagement increases the corporate evaluation, which in turn triggers product evaluation (e.g., responses to sustainability efforts in Hofenk et al. 2019; cause-related marketing in Howie et al. 2018). Moreover, perceived corporate reputation positively affects consumers' trust and thereby their intention to buy sustainable food (see meta-analysis in Ali et al. 2015).

A green empowerment ad is focused on the power shift from the company to the consumer or the relationship between them, rather than on the product itself. Therefore, we investigate how this type of ad influences consumers' corporate evaluations. According to Walsh and Beatty (2007), customer orientation and environmental responsibility represent two major aspects of corporate reputation. With a green empowerment ad, a company signals that it is willing to (1) react to customer wishes and (2) intensify environment-friendly offerings/operations, thereby triggering both corporate evaluations. Further, improved corporate evaluations might positively influence consumers' intention to buy organic foods. In the following sections, we discuss in further detail how green empowerment ads affect these corporate evaluations and thus consumers' intention to buy organic foods compared with other ad types.

\subsubsection{Customer orientation}

A customer-oriented company positions the customer as the focal point of strategic planning and execution and prioritizes its resources to meet customers' current and future needs (Brady and Cronin 2001; Deshpandé et al. 1999). Previous studies show that consumers' perceptions of a companies' customer orientation (CO) are actively manageable (Ruth and York 2004).

Consumer empowerment by involving them in the process of new product development is shown to increase the level of perceived CO (Fuchs et al. 2011). In contrast, a green appeal that is purely focused on the product's environmental benefits (instead of the product quality generally desired by consumers) can even lead to reduced perceptions of customer orientation, as consumers might infer that the company diverts resources to reach environmental goals (Newman et al. 2014). Hence, product-focused green appeals may give consumers the impression that the company prioritizes not the consumer, but the environment. Both green and non-green empowerment ads highlight the central position of consumers' choices for companies' offering and operations. They only vary in framing whether consumers' choices affect the companies' pro-environmental or general/ unspecified operations. Therefore, we expect that both types of empowerment ad have a positive effect on perceived $\mathrm{CO}$, while green appeals do not:

H1: (a) Green and (b) non-green empowerment ads have a larger positive effect on perceived $\mathrm{CO}$ than green appeals. 
Literature suggests that this greater perceived $\mathrm{CO}$ should further lead to more positive consumer reactions such as higher buying intentions for products (Fuchs et al. 2011) and services (Brady and Cronin 2001). Therefore, we hypothesize that the perceived $\mathrm{CO}$ mediates the effect of an empowerment ad on consumers' intention to buy organic food:

H2: The positive effect of (a) green and (b) non-green empowerment ads on consumers' intention to buy organic food is mediated by perceived $\mathrm{CO}$.

\subsubsection{Corporate environmental responsibility}

Previous studies report positive effects of corporate social responsibility on consumers' attitudes and intentions to buy sustainable foods (Bianchi et al. 2019; Grimmer and Bingham 2013; van Doorn et al. 2017). However, the perception of corporate environmental responsibility not only depends on the company's actual performance, but can also be influenced by its communication (Ruth and York 2004). Thus, sharing information about the environmental commitment is an essential tool to improve the environmental reputation (Wong et al. 2014).

Both green empowerment ads and green appeals communicate the company's environmental engagement in different ways. The green appeal informs consumers that the company offers environment-friendly products. The green empowerment ad shows that the company is aware of environmental challenges, is ready to take action, and will do so with the support of consumers' choices. It might be possible that individuals perceive such a green empowerment ad as "finger-pointing" at consumers and that the company is not taking the leading responsibility (Isenhour 2010). However, it could also be argued that most consumers are aware that companies would not produce an item without some evidence that consumers are going to buy it in a specific minimal volume (Shaw et al. 2006). Further, studies on CSR crisis communication show that companies can counter the negative impact of a crisis if they express a sincere and genuine interest in the environment and society (Ham and Kim 2020). Thus, the willingness to invest in environment-friendly production communicated in a green empowerment ad might be sufficient to signal the company's environmental responsibility to a similar extent as a green appeal. In contrast, a non-green empowerment ad solely stresses the company's general willingness to adapt to consumer choices, yet does not demonstrate a greater environmental responsibility.

Therefore, we expect:

H3: Green empowerment ads have (a) a similar positive effect on perceived CER as green appeals but (b) a larger effect compared with non-green empowerment ads.

H4: The positive effect of green empowerment ads on consumers' intentions to buy organic food is mediated by perceived CER. 
As hypothesized in $\mathrm{H} 2$ and $\mathrm{H} 4$, we expect that the effect of green empowerment ads on consumers' intention to buy organic food to be mediated by two factors, $\mathrm{CO}$ and CER. In contrast, we expect a positive effect of green appeals only on CER, not CO. In addition, a non-green empowerment ad should only affect one of these mediating variables (CO but not CER). Extant research indicates that a blended advertising approach combining both egoistic (e.g. related to personal health) and altruistic appeals (e.g. related to environmental concerns) produces more favorable responses compared to an appeal solely based on egoistic appeals (Kareklas et al. 2014). Therefore, we assume that the two effects of green empowerment add up and generate a larger effect on the intentions to buy organic food than a single strategy focusing only on ecological benefits (green appeal) or consumers' self-benefits (non-green empowerment ad). Following this argumentation, we propose:

H5: Green empowerment ads more effectively enhance consumers' intentions to buy organic food than (a) green appeals and (b) non-green empowerment ads.

\subsection{Corporate resources and CER}

The ability of companies to implement more sustainable production processes depends on a set of variables including technological, organizational and environmental factors (Lin and Ho 2011). In small- and medium-sized enterprises (SMEs), green innovation management is influenced, for instance, by financial resources, management style, human resources, technological approach, and innovation capacities (Del Brio and Junquera 2003). The significant impact of company size on proenvironmental adoptions and, therefore, corporate environmental performance is supported by a number of studies (Álvarez-Gil et al. 2007; Etzion 2007; GonzalezBenito and Gonzalez-Benito 2006). As a major underlying reason, sufficient organizational resources and learning capabilities are two central characteristics advancing technical innovation (Jeyaraj et al. 2006). Another reason is that large companies face higher stakeholder and consumer pressure requesting a proactive environmental strategy, as large-scale productions also have a greater environmental impact (Gonzalez-Benito and Gonzalez-Benito 2006; Seroka-Stolka and Fijorek 2020). To sum up, large companies tend to adopt innovations and environment-friendly practices more easily than small ones because they have sufficient resources and strong infrastructures (Lin and Ho 2011; Wu 2017).

In the context of food, organic farming leads to higher costs in many sub-categories compared to conventional farming (e.g., as shown for rice in Tashi and Wangchuk 2016 and other sub-categories in Klonsky 2012). Organic production faces lower expected outcomes for a similar amount of input and depends on a price premium to compensate these higher costs (Tashi and Wangchuk 2016). Smaller producers might be incapable of increasing the investment in organic production and to deal with possible risks of market difficulties and unpredictability, as organic purchase is still the exception (e.g., organic share of agricultural land in China or US: 0.6\%; Willer et al. 2020). 
However, individuals' presumption of a company's environmental responsibility based on its resources conceptually differs from the company's actual fulfillment of its environmental responsibility (e.g., Glavas and Kelley 2014). It is important to note that consumers' perceptions of CER in this sense are subjective and could be biased because, for instance, there are also SMEs that concentrate their resources or are specialized in environmentally sustainable operations. Nevertheless, some studies show that consumers perceive a higher corporate social reputation for large and financially well-performing companies compared to smaller ones with lower financial power ( $\mathrm{Lu}$ et al. 2015). In spite of the possible bias in perceptions, we need to consider that information on resources (e.g., expressed by company size, sales volume, technological advancement) might influence how consumers perceive a company's capabilities to contribute to society and environment.

A green empowerment ad promises to enhance sustainable offerings and production in response of possible consumers' demands, which would require sufficient corporate resources. Therefore, we expect perceived corporate resources to strengthen the effect of a green empowerment ad on perceived CER: the higher the perceived resources, the more positively would individuals respond to the company's CER. In contrast, when consumers perceive lower resource levels, a green empowerment ad might be less effective than a green appeal, which does not make any statement on the company's change in the extent of sustainable operations. To sum up, we hypothesize:

H6: Perceived corporate resources moderate the effect of ad type on perceived CER. More specifically, when consumers perceive high corporate resources, the green empowerment ad leads to higher perceived CER compared to when non-green empowerment ads or green appeals are used.

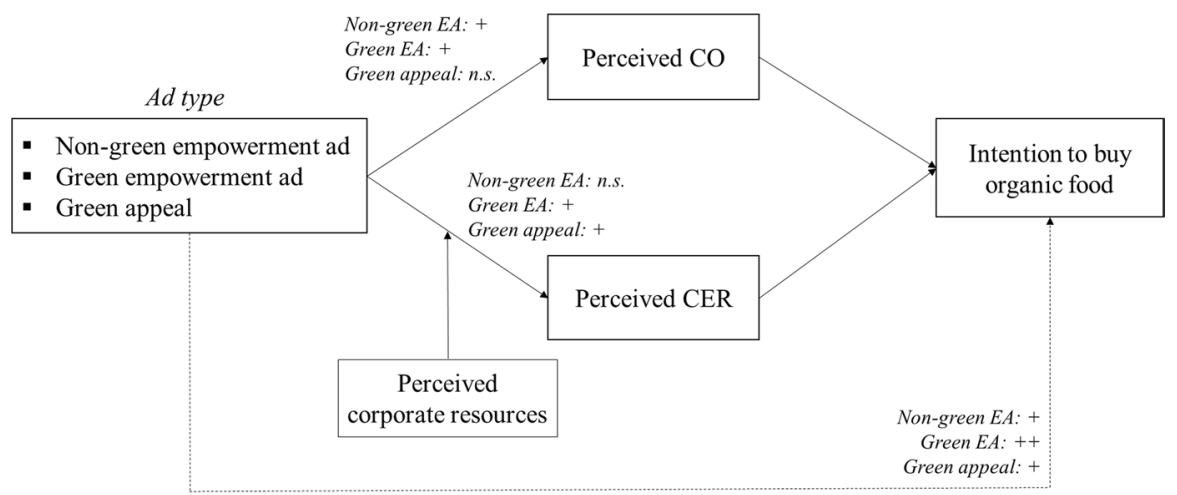

Fig. 1 Conceptual model. Note( $s)$ : $\mathrm{CO}=$ customer orientation; $\mathrm{CER}=$ corporate environmental responsibility; Green $\mathrm{EA}=$ green empowerment ad; non-green $\mathrm{EA}=$ non-green empowerment ad; n.s. = non-significant; + means one positive effect (via perceived customer orientation or perceived CER); ++ means two positive effects (via both mediators) 
Figure 1 summarizes the hypothesized effects of three experimental ad types (green empowerment, non-green empowerment, and green appeal) in a conceptual model.

\section{Study 1: Green empowerment ad versus green appeal}

Study 1 served to test the effectiveness of a green empowerment ad against a green appeal and a control group (no stimulus), as well as the mediation effects via corporate evaluations that influence consumers' purchase intentions.

\subsection{Method}

Stimuli. The green empowerment ad was designed to indicate the impact of consumers' buying decision on the green product offering and production manners of the company. The ad explicitly addressed consumer buying power and its effect on changing companies and the environment: "Use your power to move green production: By buying environment-friendly products, you can set a signal that you require us to offer more green products and to intensify environment-friendly operations. Every consumer can actively exercise buying power to influence the supplier and therefore the environment." The green appeal, in contrast, focused on the consumers' positive ecological impact by purchasing the product: "Help improve the environment: By buying environment-friendly products, you can make a step forward to reduce pollutants and to improve environmental quality. Every consumer can take care of the environment." Differently from the green empowerment ad and the green appeal, participants in the control group received no stimulus (see the Appendix, Table 8). This group served to identify potential effects caused by the stimuli in the experimental groups. We conducted single interviews with six Chinese graduate students to optimize the wording of the stimuli.

Procedure. We tested our hypotheses H1a, H2a, H3a, H4, and H5a in a surveybased online experiment with a between-subjects design (ad type: green empowerment ad vs. green appeal vs. control). We randomly assigned participants to one of the conditions. They were asked to imagine they were shopping for organic rice in an online marketplace and received some information about the product. We chose the online shopping context since online food sales account for over one third of total food expenditures and show rapid growth in China (32.5\% with an annual growth rate of $35.1 \%$ from 2014 to 2018; van Ewijk et al. 2020). Rice is chosen because it is a staple food in China, therefore, all consumers might be able to put themselves into the buying situation. Participants were directed to carefully read an advertisement message containing the experimental stimulus, which appeared for at least $10 \mathrm{~s}$. To recall the ad, participants were asked to write down the main ideas of the ad. The following survey captured participants' attitudes toward the ad and product perceptions. Next, we measured perceived power as a manipulation check, followed by the CO and CER perceptions of the company. Afterwards, participants indicated their purchase intention for the product. The 
last part of the survey captured purchase habits in daily life, message familiarity and comprehensibility, and socio-demographics.

Measures. Multi-item scales have higher reliability and validity (Diamantopoulos et al. 2012; Sarstedt and Wilczynski 2009). Therefore, we used established multi-item scales in our questionnaire: attitude toward the ad (three items; Severn et al. 1990), product perception (two items; Grant et al. 2004), perceived power (three items modified based on Fuchs et al. 2010; Spreitzer 1995), CO (four items adapted from Blocker et al. 2011; Walsh and Beatty 2007), CER (three items adapted from Turker 2009; Walsh and Beatty 2007), purchase intention (two items; Dodds et al. 1991), and social desirability (four items adapted from Crowne and Marlowe 1960). Simple and concrete constructs such as purchase habits (online and green purchase frequency), message familiarity, and comprehensibility were measured through single-items (Petrescu 2013; see Appendix Table 9 for a full list of items and related constructs). The questionnaire was composed in English and translated into Mandarin Chinese using the iterative approach, which strives for conceptual equivalence rather than literal translation (Douglas and Craig 2007). All constructs showed satisfactory reliability levels (Cronbach's alpha $>0.70)$ as well as high factor loadings $(>0.70$; Appendix Table 9), except for the social desirability scale (Cronbach's alpha $=0.55$ ), which is nonetheless within the Marlowe-Crowne Scale acceptable range of between 0.50 and 0.75 (Loo and Loewen 2004).

Sample. In total, we recruited 311 Chinese consumers through an online survey platform (Weidiaocha.com). Participants received a monetary reward as an incentive. We excluded 17 respondents who did not recall the ad message correctly. This resulted in a final sample of 294 respondents (sample size per group: $\mathrm{n}_{\text {GreenPower }}=104, \mathrm{n}_{\text {GreenAppeal }}=98, \mathrm{n}_{\text {Control }}=92$ ), with $63.8 \%$ female respondents and age ranging between 17 and 55 years $(M=28.1$ years, $S D=6.11$ years $)$. The majority $(95 \%)$ held a university degree.

Manipulation check and descriptive statistics. The manipulation check confirmed that respondents experienced a higher degree of power over the company's decisions after reading the green empowerment ad than in the green appeal or control group $\left(M_{\text {GreenPower }}=4.97, M_{\text {GreenAppeal }}=4.28, M_{\text {Control }}=4.02, \quad F(2\right.$, $291)=11.74, p<0.001)$. In addition, results were not confounded by group differences on non-manipulated variables: message familiarity did not differ significantly between the three groups $\left(M_{\text {GreenPower }}=4.84, M_{\text {GreenAppeal }}=4.58\right.$, $\left.M_{\text {Control }}=4.58 ; F(2,291)=1.19, p=0.31\right)$, and the same applies to message comprehensibility (low mean scores indicating high comprehensibility: $M_{\text {GreenPower }}=3.16, \quad M_{\text {GreenAppeal }}=2.72, \quad M_{\text {Control }}=2.95 ; \quad F(2,291)=2.08$, $p=0.13)$. However, attitudes toward the ads differed: participants evaluated the green empowerment/ green appeal ads more positively than the control group: $M_{\text {GreenPower }}=5.02, M_{\text {GreenAppeal }}=5.03, M_{\text {Control }}=4.47 ; F(2,291)=5.35$, $p<0.01$. Further, participants evaluated the product better in the green empowerment group than in the control group $\left(\mathrm{M}_{\text {GreenPower }}=5.40, \mathrm{M}_{\text {GreenAppeal }}=5.23\right.$, $\left.\mathrm{M}_{\text {Control }}=4.95 ; F(2,291)=3.20, p<0.05\right)$. We observed no significant differences between green empowerment ads and green appeals regarding the attitude toward the ad and the product evaluation. 


\subsection{Results}

\subsubsection{Effects of green empowerment on corporate evaluations and purchase intention}

We performed three analyses of variance (ANOVAs) with post hoc tests to test the effect of ad type on CO, CER, and purchase intention (see Table 1). We found significant main effects of the ad type on all outcome variables. Participants indicated higher $\mathrm{CO}$ after reading the green empowerment ad than in the green appeal and the control group (in support of H1a). For CER, we found a significant difference between the green empowerment ad and the control group ad but not to the green appeal (confirming H3a). The green appeal also significantly increased environmental responsibility compared with the control group. The green empowerment ad has a more positive effect on purchase intentions than the other two groups, which supports H5a. In contrast, the green appeal did not significantly improve $\mathrm{CO}$ or purchase intention compared to the control group.

\subsubsection{Mediation effects of corporate evaluations}

To better understand the indirect effects of ad type on purchase intentions, we conducted a parallel mediation analysis using PROCESS model 4 (95\% percentile bootstrap confidence intervals with 5,000 resamples; Hayes 2018). The independent variable (ad type) was included as multi-categorical variable with the control group as baseline. We added purchase habits, social desirability, and socio-demographics (gender, age, education) to the model as covariates.

The mediation analysis confirms the indirect effect of the green empowerment ad through CO $(b=0.21,95 \%$ CI $[0.06 ; 0.42])$ and CER $(b=0.28,95 \%$ CI $[0.13$;

Table 1 Effects of ad type on CO, CER, and purchase intention (ANOVAs)

\begin{tabular}{|c|c|c|c|}
\hline$M$ & Sign. group differences & $F$ & Hypothesis \\
\hline \multicolumn{4}{|l|}{$\mathrm{CO}$} \\
\hline $\begin{array}{l}\text { Green empowerment ad: } 5.44 \\
\text { Green appeal: } 4.96 \\
\text { Control: } 4.87\end{array}$ & Green empowerment ad $>$ Green appeal/Control & $7.27 * *$ & H1a: $\checkmark$ \\
\hline \multicolumn{4}{|l|}{$C E R$} \\
\hline $\begin{array}{l}\text { Green empowerment ad: } 5.54 \\
\text { Green appeal: } 5.27 \\
\text { Control: } 4.75\end{array}$ & $\begin{array}{l}\text { Green empowerment ad }>\text { Control } \\
\text { Green appeal }>\text { Control }\end{array}$ & $11.93 * * *$ & Н3а: $\checkmark$ \\
\hline \multicolumn{4}{|l|}{ Purchase intention } \\
\hline $\begin{array}{l}\text { Green empowerment ad: } 5.41 \\
\text { Green appeal: } 4.83 \\
\text { Control: } 4.71\end{array}$ & Green empowerment ad $>$ Green appeal/Control & $7.40 * *$ & Н5а: $\checkmark$ \\
\hline
\end{tabular}

$\bar{\dagger} p<0.10, * p<0.05, * * p<0.01$, *** $p<0.001$; one-way ANOVAs with Scheffé post hoc tests $(p<0.05)$;

$C O$ customer orientation; $C E R$ corporate environmental responsibility 
Table 2 Relative indirect effects on purchase intention (parallel mediation analysis)

\begin{tabular}{|c|c|c|c|c|c|c|}
\hline & \multicolumn{3}{|c|}{ Indirect effects via $\mathrm{CO}$} & \multicolumn{3}{|c|}{ Indirect effects via CER } \\
\hline & $b$ & CI [LB; UB] & Hypothesis & $b$ & CI [LB; UB] & Hypothesis \\
\hline Green empowerment ad & $0.21 *$ & $0.06 ; 0.42$ & $\mathrm{H} 2 \mathrm{a}: \boldsymbol{}$ & $0.28 *$ & $0.13 ; 0.47$ & $\mathrm{H} 4: \checkmark$ \\
\hline Green appeal & 0.11 & $-0.00 ; 0.25$ & & $0.22 *$ & $0.08 ; 0.41$ & \\
\hline
\end{tabular}

$C I$ Confidence intervals, $L B$ lower bound, $U B$ upper bound, $C O$ customer orientation, $C E R$ corporate environmental responsibility

* Significant (percentile 95\% CI, n=5,000 bootstrap samples);

Table 3 Relative direct and total effects of ad type on purchase intention (parallel mediation analysis)

\begin{tabular}{|c|c|c|c|c|c|}
\hline & \multicolumn{2}{|c|}{ Relative direct effects } & \multicolumn{2}{|c|}{ Relative total effects } & \multirow[b]{2}{*}{ Hypothesis } \\
\hline & $b$ & $\mathrm{SE}(\mathrm{HC} 3)$ & $b$ & $\mathrm{SE}(\mathrm{HC} 3)$ & \\
\hline Green empowerment ad & 0.21 & 0.18 & $0.69 * * *$ & 0.19 & Н5а: $\checkmark$ \\
\hline Green appeal & -0.11 & 0.16 & 0.23 & 0.19 & \\
\hline
\end{tabular}

${ }^{\dagger} p<0.10, * p<0.05, * * p<0.01$, *** $p<0.001$; baseline: control group; $\mathrm{SE}(\mathrm{HC} 3)=$ heteroscedasticityconsistent standard error estimators; total effect $=$ direct effect + indirect effects via $\mathrm{CO}$ and CER

0.47]; see Table 2), which confirms H2a and H4. As a mediated effect exists but no significant direct effect on purchase intention (see Table 3), we can confirm a fully mediated effect (Zhao et al. 2010). The effect of the green appeal is fully mediated by CER $(b=0.22,95 \%$ CI $[0.08 ; 0.41]$; Table 2$)$. Further, the total effect of the green empowerment ad on purchase intentions is highly significant $(b=0.68$, $p<0.001$; Table 3 ), whereas the green appeal has a smaller, non-significant total effect ( $b=0.23, p>0.10$; Table 3$)$, which again supports H5a.

In summary, we can conclude from Study 1 that the green empowerment ad outperforms both the control group and the green appeal. The green empowerment ad and the green appeal increase the perceived environmental responsibility of the company. Only the green empowerment ad leads to significantly greater perceptions of CO and significantly improves purchase intention. Study 1 shows the effects of a green empowerment ad on corporate evaluations and their mediating effect on purchase intention. Study 2 focuses on the moderating effect of perceived corporate resources and extends previous experimental conditions with a general, non-green empowerment ad.

\section{Study 2: Green and non-green empowerment ad and the moderating effect of perceived corporate resources}

Study 1 showed that perceived CER is an important mediator driving purchase intentions. As expected, we also found that the CER perceptions were increased as much by the green empowerment ad as by the green appeal. The former performed 
better because it also increased $\mathrm{CO}$ and the positive effects via $\mathrm{CO}$ and CER were additive. We proposed that this addition of effects should lead to an advantage over not only green appeals but also non-green empowerment ads only focusing on a company's $\mathrm{CO}$ (see H3b and H5b). Therefore, we conducted a second study aiming to (a) replicate the effect of a green empowerment ad in a different sample, (b) test both green and non-green empowerment ads, and (c) examine potential differences for different levels of perceived corporate resources (high vs. low).

\subsection{Method}

We employed a 4 (ad type: green empowerment ad vs. non-green empowerment ad vs. green appeal vs. control) $\times 3$ (corporate resources: high resources vs. low resources vs. control) full factorial between-subjects design.

Stimuli and procedure. First, respondents saw the same product information as in Study 1 . Then, they viewed the Study 1 stimuli for the green empowerment ad, the green appeal ad, and neutral information in the control group. We added a non-green empowerment ad, which emphasizes the consumers' power to influence suppliers' production without explicitly mentioning environment-friendliness: "Use your power to move production: By making product choices, you can set a signal that you require us to offer more of the chosen products and to intensify related operations. Every consumer can actively exercise buying power to influence the supplier." To manipulate the perceived corporate resources, two groups received information about the company's high vs. low resource availability through indicators such as turnover (high: 91.4b Yuan; low: 914,000 Yuan), number of employees (high: 323,000; low: 30), and technological advancement (high: "highly innovative technologies"; low: "technologies of long tradition"; see Appendix Table 8), while the control group received no company information. A separate pretest $(n=215)$ confirmed that this information is sufficient to influence perceived corporate resources: Information showing high resources based on discussed indicators led to significantly higher perceived corporate resources $(M=6.14)$ compared to information showing low resources $(M=3.67 ; F(1,211)=219.91, p<0.001)$.

Measures. We applied the same measures as in Study 1 and used a self-developed manipulation check for perceived corporate resources (two items; see Appendix Table 9). We added a measure of the perception of product quality as a third item for product evaluation as control variable (Grant et al. 2004). All constructs showed satisfactory reliability levels (Cronbach's alpha $>0.80$ ) as well as high factor loadings ( $>0.70$; Appendix ATable 9 except for the social desirability scale (Cronbach's alpha $=0.54$ ), which is still an acceptable rate according to Loo and Loewen (2004).

Sample. We collected data from 530 Chinese consumers, recruited through the same online survey platform used in Study 1 (Weidiaocha.com). Participants received a monetary reward as incentive. We excluded 73 respondents who did not pass an attention check requiring a certain answer (see Paas et al. 2018), resulting in a sample of 457 respondents. The sample consists of $66.3 \%$ female respondents (average age: $M=27.32$ years, $S D=6.4$ years). Participants' education level was high: $87.5 \%$ held a university degree. 
Manipulation checks and descriptive statistics. The manipulation check confirms that respondents experienced a higher degree of power over the company's decisions after reading the green/non-green empowerment ads compared with both the green appeal and control group ad $\left(M_{\text {GreenPower }}=4.82, M_{\text {Power }}=4.74, M_{\text {GreenAppeal }}=4.07\right.$, $\left.M_{\text {Control }}=3.90, F(3,453)=10.98, p<0.001\right)$. Further, perceived corporate resources reached highest scores in the high-resource condition, followed by the control and the low-resource group, with significant differences between all three groups (perceived corporate resources: $M_{\mathrm{High}}=5.71, M_{\mathrm{Low}}=4.28, M_{\mathrm{Control}}=5.19, F(2,454)=43.06$, $p<0.001)$. As in Study 1, we found that the attitude toward the green appeal is more positive than toward the control group, but we observed no significant differences between the other three ads: $M_{\text {GreenPower }}=5.21, M_{\text {Power }}=5.05, M_{\text {GreenAppeal }}=5.32$, $\left.M_{\text {Control }}=4.43, F(3,453)=8.32, p<0.001\right)$. Participants evaluated product quality better in the empowerment groups than in the control group $\left(M_{\text {GreenPower }}=5.54\right.$, $\left.M_{\text {Power }}=5.48, M_{\text {GreenAppeal }}=5.42, M_{\text {Control }}=5.04 ; F(3,453)=3.67, p=0.01\right)$.

\subsection{Results}

\subsubsection{Effects of green empowerment ads on corporate evaluations and purchase intention}

We applied two-way ANOVAs to test the effects of ad type and perceived corporate resources on $\mathrm{CO}, \mathrm{CER}$, and purchase intention. We observed significant main effects of both the ad type and perceived corporate resources on CO (see Table 4). Both green and non-green empowerment ads $\left(M_{\text {GreenPower }}=5.59, M_{\text {Non-GreenPower }}=5.78\right)$ significantly increased CO compared with the green appeal $\left(M_{\text {GreenAppeal }}=5.13\right.$; Table 4). The effect of the empowerment ads is significantly larger compared with the green appeal, which confirms H1a (as in Study 1) and H1b. In contrast, low perceived corporate resources have a negative effect, significantly reducing the $\mathrm{CO}$ perception compared with the control group $\left(M_{\text {Low }}=5.16\right.$ vs. $M_{\text {Control }}=5.62$; Table 4; also see Appendix Fig. 3).

For CER, we find a significant main effect of ad type and an interaction effect with perceived corporate resources (see Table 4). As expected ( $\mathrm{H} 3 \mathrm{a}$ and $\mathrm{H} 3 \mathrm{~b}$ ), the green empowerment ad increases CER compared with the control group and the non-green empowerment ads, but we observed no significant difference compared with the green appeal. Hence, results from Study 1 regarding the effect of green empowerment ad on CER (H3a) are replicated. Further, the significant interaction effect confirms H6. A simple main effects analysis shows that the effect of the green empowerment ad on CER is significantly larger in the high-resource group (compared with the low-resource group, $p<0.05 ; F(2,445)=4.67, p<0.05$; see Fig. 2), but not compared with the control group. In contrast, the green appeal has the same effect for all resource groups $(F(2,445)=0.05, p>0.10)$. Further, the simple main effects analysis shows that for high-resource companies, there are significant differences between ad types $(F(3,445)=8.48, p<0.001)$. Both green empowerment ad and green appeal perform well: perceived CER was rated significantly higher for these ad types than the non-green empowerment ad $(p<0.05)$ and the control group 
Table 4 Effects of ad type and perceived corporate resources on CO, CER, and purchase intention (twoway ANOVAs)

\begin{tabular}{|c|c|c|c|c|}
\hline & $M$ & Sign. group differences & $F$ & Hypothesis \\
\hline \multicolumn{5}{|l|}{$\mathrm{CO}$} \\
\hline $\mathrm{Ad}$ & $\begin{array}{l}\text { Green EA: } 5.59 \\
\text { Non-green EA: } 5.78 \\
\text { Green appeal: } 5.13 \text { Control: } \\
5.20\end{array}$ & $\begin{array}{l}\text { Green EA }>\text { Green appeal } \\
\text { Non-green EA }>\text { Green appeal/ } \\
\text { Control }\end{array}$ & $7.26^{* * * *}$ & $\begin{array}{l}\text { H1a: } \checkmark \\
\text { H1b: } \checkmark\end{array}$ \\
\hline Resources & $\begin{array}{l}\text { Control: } 5.62 \\
\text { High: } 5.42 \\
\text { Low: } 5.16\end{array}$ & Control $>$ Low & $4.90 * *$ & \\
\hline Ad*Resourc & & & 0.60 & \\
\hline \multicolumn{5}{|l|}{ CER } \\
\hline $\mathrm{Ad}$ & $\begin{array}{l}\text { Green EA: } 5.44 \\
\text { Non-green EA: } 4.80 \\
\text { Green appeal: } 5.76 \\
\text { Control: } 4.68\end{array}$ & $\begin{array}{l}\text { Green EA > Non-green EA / } \\
\text { Control } \\
\text { Green appeal > Non-green EA } \\
\text { / Control }\end{array}$ & $16.49 * * *$ & $\begin{array}{l}\text { H3a: } \checkmark \\
\text { H3b: } \checkmark\end{array}$ \\
\hline Resources & $\begin{array}{l}\text { Control: } 5.29 \\
\text { High: } 5.18 \\
\text { Low: } 4.98\end{array}$ & - & $3.01^{\dagger}$ & \\
\hline Ad*Resourc & & & $2.30^{*}$ & H6: $\checkmark$ \\
\hline \multicolumn{5}{|c|}{ Purchase intention } \\
\hline Ad & $\begin{array}{l}\text { Green EA: } 5.31 \\
\text { Non-green EA: } 5.12 \\
\text { Green appeal: } 4.95 \\
\text { Control: } 4.77\end{array}$ & Green EA $>\mathrm{Control}^{\dagger}$ & $2.55^{\dagger}$ & $\begin{array}{l}\text { H5a: } \times \\
\text { H5b: } \times\end{array}$ \\
\hline Resources & $\begin{array}{l}\text { Control: } 5.21 \\
\text { High: } 5.17 \\
\text { Low: } 4.73\end{array}$ & Control/ High $>$ Low & $4.17 *$ & \\
\hline $\mathrm{Ad} *$ Resourc & & & 0.36 & \\
\hline
\end{tabular}

$E A$ empowerment ad; adad type; resources perceived corporate resources; $C O$ customer orientation; CER corporate environmental responsibility

${ }^{\dagger} p<0.10, * p<0.05, * * p<0.01, * * * p<0.001$; two-way ANOVAs with Scheffé post hoc tests $(p<0.05)$

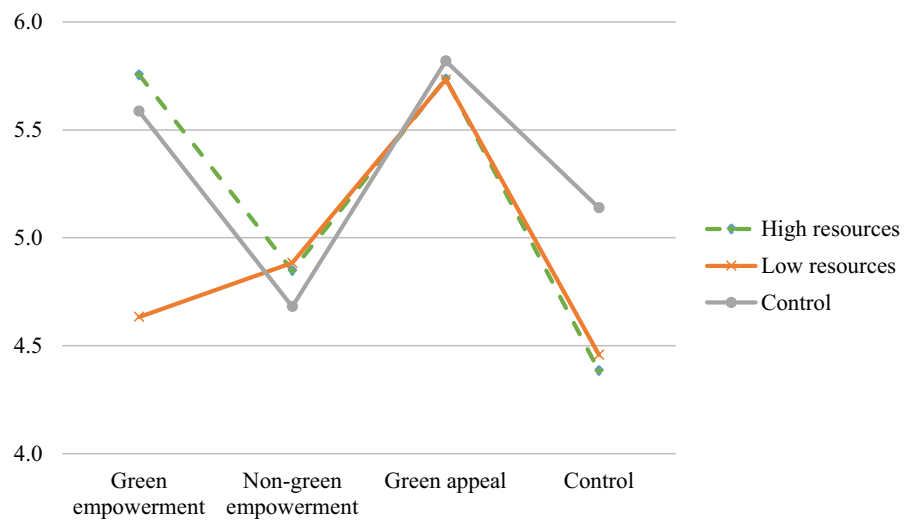

Fig. 2 Means for CER 
$(p<0.001)$. In contrast, for low-resource companies, the green appeal is most effective and leads to significantly higher CER ratings than all other ads $(F(3,445)=7.30$, $p<0.001$; green appeal vs. green/non-green empowerment ad: $p<0.05$, green appeal vs. control: $p<0.001$; see Fig. 2). Thus, the green appeal improved perceived CER independently from perceived corporate resources, whereas the green empowerment effect disappeared in the low-resource group.

Regarding the purchase intention, we find a marginally significant direct effect of the ad type (see Table 4). The green empowerment ad is the only ad, which has a marginally significant effect on purchase intention compared to the control group. The observed differences to the non-green empowerment ad and the green appeal are too small to approach significance. Therefore, H5a and H5b cannot be confirmed in Study 2. There is a significant effect of perceived corporate resources: consumers are less willing to buy from low-resource companies (see Table 4 and Appendix Fig. 3).

\subsubsection{Mediation effects of corporate evaluations}

As in Study 1, we conducted a parallel mediation analysis using PROCESS model 4 (95\% percentile bootstrap confidence intervals with 5,000 resamples; Hayes 2018). We included ad type as independent, multi-categorical variable (control group as baseline) and added purchase habits, social desirability, and socio-demographics (gender, age, education) as covariates.

The green empowerment ad has significant indirect effects on purchase intention through CO $(b=0.11,95 \%$ CI $[0.02 ; 0.23])$ and CER $(b=0.27,95 \%$ CI $[0.13$; 0.42]; see Table 5), in line with $\mathrm{H} 2 \mathrm{a}$ and $\mathrm{H} 4$. There is no significant direct effect on purchase intention (see Table 6), thus, the effect is fully mediated (Zhao et al. 2010). The effect of the green appeal is fully mediated by CER $(b=0.47,95 \%$ CI $[0.31 ; 0.66]$; Table 5), whereas the effect of the non-green empowerment ad is fully mediated by $\mathrm{CO}(b=0.18,95 \%$ CI $[0.08 ; 0.31]$; Table 5 ; supporting $\mathrm{H} 2 \mathrm{~b})$. The green empowerment ad has the largest total effect on purchase intention $(b=0.45$, $p<0.01$; Table 6), followed by the green appeal and the non-green empowerment ad $(b=0.38 / 0.36, p<0.05$; Table 6). Thus, in comparison to the control group, all ad types drive purchase intention.

Table 5 Relative indirect effects on purchase intention (parallel mediation analysis)

\begin{tabular}{|c|c|c|c|c|c|c|}
\hline & \multicolumn{3}{|c|}{ Indirect effects via $\mathrm{CO}$} & \multicolumn{3}{|c|}{ Indirect effects via CER } \\
\hline & $b$ & $\mathrm{CI}[\mathrm{LB} ; \mathrm{UB}]$ & Hypothesis & $B$ & $\mathrm{CI}[\mathrm{LB} ; \mathrm{UB}]$ & Hypothesis \\
\hline Green empowerment ad & $0.11^{*}$ & $0.02 ; 0.23$ & $\mathrm{H} 2 \mathrm{a}: \boldsymbol{}$ & $0.27 *$ & $0.13 ; 0.42$ & $\mathrm{H} 4: \boldsymbol{}$ \\
\hline Non-green empowerment ad & $0.18^{*}$ & $0.08 ; 0.31$ & $\mathrm{H} 2 \mathrm{~b}: \boldsymbol{}$ & 0.02 & $-0.11 ; 0.16$ & \\
\hline Green appeal & 0.01 & $-0.08 ; 0.10$ & & $0.47 *$ & $0.31 ; 0.66$ & \\
\hline
\end{tabular}

$C I$ Confidence intervals, $L B$ lower bound, $U B$ upper bound, $C O$ customer orientation, $C E R$ corporate environmental responsibility

*Significant (percentile $95 \% \mathrm{CI}, \mathrm{n}=5,000$ bootstrap samples; 
Table 6 Relative total and direct effects of ad type on purchase intention (parallel mediation analysis)

\begin{tabular}{|c|c|c|c|c|c|}
\hline & \multicolumn{2}{|c|}{ Relative direct effects } & \multicolumn{2}{|c|}{ Relative total effects } & \multirow[b]{2}{*}{ Hypothesis } \\
\hline & $b$ & $\mathrm{SE}(\mathrm{HC} 3)$ & $b$ & $\mathrm{SE}(\mathrm{HC} 3)$ & \\
\hline Green empowerment ad & 0.08 & 0.14 & $0.45 * *$ & 0.15 & $\mathrm{H} 5 \mathrm{a} / \mathrm{b}: \times$ \\
\hline Non-green empowerment ad & 0.15 & 0.14 & $0.36^{*}$ & 0.16 & \\
\hline Green appeal & -0.10 & 0.14 & $0.38 *$ & 0.16 & \\
\hline
\end{tabular}

Baseline: control group; $\mathrm{SE}(\mathrm{HC} 3)=$ heteroscedasticity-consistent standard error estimators; total effect $=$ direct effect + indirect effects via $\mathrm{CO}$ and CER

${ }^{\dagger} p<0.10, * p<0.05, * * p<0.01, * * * p<0.001$;

\subsubsection{Moderated mediation by perceived corporate resources}

Previous results indicate that the ad type interacts with perceived corporate resources regarding the effect on perceived CER (see Table 4). To determine whether the mediation effects via perceived CER are moderated, we additionally conducted a moderated mediation analysis using PROCESS model 7, including perceived corporate resources as a multi-categorical moderator variable $(95 \%$ percentile bootstrap confidence intervals with 5000 resamples; Hayes 2018). The omnibus test confirms that a significant interaction occurs between Ad*Resource for the effect on CER $\left(R_{\text {change }}^{2}=0.03 ; p<0.001\right.$; in line with H6), while no interaction occurs between $\mathrm{Ad}^{*}$ Resource for the effect on CO $\left(R_{\text {change }}^{2}=0.01 ; p>0.10\right)$. Specifically, for the effect on CER, there are three positive, significant interaction terms: Green Empowerment Ad*High Resources ( $b=0.89 ; p<0.05)$, Non-green Empowerment Ad*Low Resources $(b=1.04 ; p<0.05)$, and Green Appeal $*$ Low Resources $(b=1.06$; $p<0.01)$.

We find that the mediation effects via CER differ, moderated by perceived corporate resources (Table 7). First, the mediation effect of the green empowerment ad is only significant in the high-resource group $(b=0.48 ; 95 \% \mathrm{CI}[0.25 ; 0.74])$. The difference between conditional indirect effects is significant as well (high resources

Table 7 Relative conditional indirect effects of ad type (moderated mediation analysis)

\begin{tabular}{llll}
\hline & \multicolumn{2}{l}{ Indirect effect via CER } & \\
\cline { 2 - 4 } \cline { 3 - 3 } & $\begin{array}{l}\text { Green empower- } \\
\text { ment ad }\end{array}$ & $\begin{array}{l}\text { Non-green empower- } \\
\text { ment ad }\end{array}$ & Green appeal \\
\hline Control & 0.13 & -0.20 & $0.27^{*}$ \\
High resources & $0.48^{*}$ & 0.11 & $0.46^{*}$ \\
Low resources & 0.09 & 0.20 & $0.69^{*}$ \\
Index of moderated mediation $\left(\mathrm{I}_{\mathrm{MM}}\right)$ & & & 0.19 \\
$\mathrm{I}_{\mathrm{MM}}$ : High (vs. control) & $0.35^{*}$ & 0.31 & $0.42 *$ \\
$\mathrm{I}_{\mathrm{MM}}$ : Low (vs. control) & -0.03 & $0.41^{*}$ & \\
\hline
\end{tabular}

CER corporate environmental responsibility

* Significant (percentile 95\% CI; $\mathrm{n}=5,000$ bootstrap samples); 
vs. control; $\mathrm{I}_{\mathrm{MM}}=0.35 ; p<0.05$; Table 7 ). The mediation effect of the green appeal is significant in all groups (Table 7), yet differs in magnitude: the mediation effect is significantly larger in the low-resource group $(b=0.69 ; 95 \%$ CI $[0.43 ; 0.99])$ than in the control group $(b=0.46 ; 95 \%$ CI $[0.22 ; 0.74]) ; \mathrm{I}_{\mathrm{MM}}=0.42 ; p<0.05$; Table 7). As reported before, there are no significant mediation effects of the non-green empowerment ad via CER (Table 7). Overall, the analysis supports the conclusion that the mediation effects of CER are moderated by the resource conditions: in particular, the green empowerment ad is only effective for high-resource companies.

In summary, Study 2 shows that a green empowerment ad outperforms both a non-green empowerment ad and a green appeal, as it is able to simultaneously increase consumers' perceptions of CO and CER, which is in line with Study 1. In addition, Study 2 shows that the perception of corporate resources also influences ad effectiveness: The effect of the green empowerment ad on perceived CER is diminished for low-resource companies.

According to results of both Study 1 and 2, we find full support for all hypotheses, except of $\mathrm{H} 5 \mathrm{a} / \mathrm{b}$ (effect of ad type on purchase intentions). H5a (green empowerment ad outperforms green appeal in increasing purchase intentions) is accepted in Study 1 but rejected in Study 2, where we find a descriptive, yet non-significant difference. Further, H5b (green empowerment ad outperforms non-green empowerment ad in increasing purchase intentions) is rejected in Study 2. We discuss these results in the following section.

\section{Discussion}

\subsection{Theoretical and managerial implications}

In two experimental studies, we investigated a new approach for advertising environment-friendly products that effectively increases consumers' beliefs about their power over the company's (pro-environmental) activities. Empowered individuals show improved perceptions of the company's CO and CER. Compared to green and non-green empowerment ads, consumers do not feel empowered by a green appeal, which is often used in advertising practice, and perceptions of CO are not enhanced. This can be understood that when advertisements for sustainable products only emphasize their benefits for the environment, consumers might consider the company's efforts on environmental protection to compete with those on fulfilling their personal needs and that they do not have power to change the company's decisions (in accordance with Newman et al. 2014). The green appeal does not contribute to increase consumers' felt power that they can specifically exercise on companies, which is, however, a significant driver of customer orientation. Furthermore, a nongreen empowerment ad increases consumers' power beliefs but does not contribute to the perception of corporate environmental responsibility. In contrast, a green empowerment ad achieves a simultaneous, complementary effect on two important dimensions of corporate evaluation, $\mathrm{CO}$ and CER, which in turn drive consumers' intentions to buy organic foods. Thus, both green appeals and non-green empowerment ads are less effective because they only affect a single dimension. 
Positive results of green empowerment ads on perceptions of CER are in line with our expectations that empowering consumers to take the lead in environmental conservation through their purchase choices do not cause any adverse effects, such as "finger-pointing" (see Isenhour 2010; as discussed in Sect. 2.2.2). Companies' genuine interests to promote sustainable consumption and to "collaborate" with consumers can be expressed through the concept of green consumer empowerment.

This research extends the existing literature on green advertising by showing the applicability of empowerment elements in the communication for environmentally sustainable products. Findings support the results of previous studies on consumer empowerment in the product design process (Jacobsen et al. 2020), in that empowerment has positive effects on $\mathrm{CO}$ and intention to buy sustainable food. The present article emphasizes the importance of corporate evaluations as mediators between green advertisements and consumers' intention to buy sustainable foods, supplementing extant research that focuses on consumers' product evaluations (e.g., Grimmer and Woolley 2014; Ramirez et al. 2015) and their ability to perform a certain behavior (White et al. 2011).

Further, we show that perceived $\mathrm{CO}$ as a buyer's benefit and perceived CER as a public benefit can coexist without negative interference, if both aspects are triggered by an ad and if the companies' resources are perceived as large enough. This finding indicates the evaluation mechanism in individuals' minds that strives to optimize several factors of a supplier's performance at the same time, for which the needs for corporate resources could conflict. It is likely that green appeals signal to the consumer that a company uses most of its attention and resources to become more environment-friendly, while neglecting customer needs.

Newman et al. (2014) argue that explicitly emphasizing a product's environmental benefits negatively affects the product quality evaluation because consumers assume that resources are deducted from product quality to enhance sustainability. We could not confirm this. In both studies, the product ratings did not differ significantly between the three investigated ad types, although we acknowledge results probably depend on the advertised product category. Newman et al. (2014) examined ads for cleaning products, whose primary product property is a strong cleaning performance. Luchs et al. (2010) show that consumers associate sustainable products with gentleness-related attributes, so if the primary product property is strength-related (e.g., cleaning performance), non-sustainable products might be preferred. Sustainable food consumption is, however, mainly driven by health and taste perceptions (e.g., Prada et al. 2017; Rana and Paul 2017), which fit the "gentleness" associated with sustainability in general (Luchs et al. 2010). Therefore, emphasizing sustainable product attributes probably does not have a negative effect on the perceived product quality here. However, a pure focus on environmental aspects does not seem advisable, supporting Newman et al.'s (2014) recommendations. The focus of the consumer in classic green appeals seems to be entirely directed toward sustainability as a buying motive, whereby other potentially important factors such as the company's CO no longer have any influence. The present study proves $\mathrm{CO}$ to be a decisive additional driver for purchasing decisions that should be addressed in advertisements. 
The present paper also revealed that consumers react differently when receiving information on the company's resource level, i.e., indicated through company size. Thus, different implications for managers of small and large companies can be derived. Small companies face the challenge that consumers tend to consider them as less customer-oriented and are less likely to buy their products (in line with Lu et al. 2015). Thus, marketers should generally be cautious with communicating that the product is produced by a small company. Even though small companies benefit significantly less from green empowerment ads (compared to large companies), this is still the most effective communication strategy to drive purchase intentions (see Appendix Fig. 3). The reason for this difference is that small companies are not perceived as more environmentally responsible when using a green empowerment ad. Consumers seem to share the belief that SMEs are more restricted in terms of corporate resources and expertise and, thus, have more difficulty becoming environmentfriendly (Wu 2017). Thus, we recommend that a small company should use green empowerment ads, but needs to signal to consumers that it is actually able to manage these changes. Green appeals do not focus on a company's proposed environmental investments in the future (when it is unsure whether they can be achieved) but on the current environmental benefit of the product. Even though they are less effective to increase purchase intentions, green appeals can be used by small companies if they aim to specifically improve their environmental reputation or target a respective customer group.

For large companies, we advocate the use of green empowerment ads to boost the corporate evaluations on both dimensions, customer orientation and environmental responsibility. Green empowerment ads are equally effective in terms of increasing purchase intentions for both large companies and if consumers are not specifically informed about the company size. Thus, marketers should focus the communication on the empowerment ad instead of emphasizing corporate characteristics.

Reflecting the cultural dimension, the presented research was conducted in China, which is representative for a centralized system with a higher level of power distance (e.g., Spencer-Oatey 1997) and shows that the suggested empowerment approach performs well, even if stronger beliefs in hierarchy exist. For more egalitarian contexts (e.g., Western countries; Schwartz 2007), an empowerment approach could possibly reach even better performance, as individuals likely see more balanced power relations with companies as desirable. Future research should investigate this possibility, as we discuss further in the "Limitations and future research" section.

Overall, our results suggest that companies should apply the principles of a green empowerment ad, as a companies' perceived CO and CER can be triggered simultaneously, which leads to the largest total positive effects on consumers' intentions to buy organic foods. Although a non-green empowerment ad can also affect perceived $\mathrm{CO}$ at a similar level, the green version has the potential to additionally contribute to image differentiation or the establishment of an environmental reputation. The possibility of boosting the intention to buy organic food by a green empowerment ad applies across company sizes and resource capacities. However, if the primary goal of smaller companies is to increase perceived CER in specific cases, green appeals serve to achieve this effect. 


\subsection{Limitations and future research}

Several limitations should be addressed in future research. Both studies presented herein deliver results based on survey data, which might be affected by the intention-behavior gap (e.g., Sudbury-Riley and Kohlbacher 2016). In the future, actual behavioral data should be collected to evaluate the practical relevance of the green empowerment approach. The effects on intentions could dilute according to previous evidence on the social desirability bias (Crowne and Marlowe 1960). However, the achievement of actual purchase power over companies fulfills with carrying out purchase actions, which could strengthen the perception of power and therefore enhance the performance of empowerment ads to a further extent. In addition, it is an open question to answer in future research which subsequent effects a green consumer empowerment can cause, for example, if consumers also feel more personal environmental responsibility (e.g., Montgomery and Stone 2009). Moreover, our results need to be validated for the offline shopping context where consumers might be distracted by a larger number of stimuli in the physical environment (e.g., Burke 1997).

Furthermore, people might change their perceptions of power over a company and their evaluations of the company's $\mathrm{CO}$ if they have repetitive interactions with it (e.g. Park and Reber 2008). We used fictitious company examples, so results might differ in a more realistic setting with known brands and previous product experience. Overall, future research should uncover the long-term effects of continuous customer-oriented green advertising.

We conducted our study in a Chinese context, which represents specific political and cultural features. Previous studies indicate that the mechanism of how certain beliefs affect Chinese consumers' intention to buy sustainable foods is comparable to studies in Western countries (Thøgersen and Zhou 2012). However, future studies should investigate whether potential cross-country differences in people's desire for power and environmental values might affect the effectiveness of green empowerment. In addition, our sample consists of predominantly younger and more-educated people. Older respondents and those without a university degree are necessary to make representative conclusions.

We tested the empowerment ad only for the organic food product category. Future studies should replicate ours with a wider range of products to identify potential category effects such as product involvement (McDonald et al. 2009; Zhou et al. 2012). The more involved or committed the consumer is to buy a specific product, the more power he or she would want to influence the product design and offering (Bügel et al. 2011). Thus, a green empowerment ad might be even more effective for high involvement products. Moreover, for some categories such as computer electronics, scholars have found a negative effect of showing sustainability labels on people's willingness to pay (e.g., Haase et al. 2016). Whether green empowerment ads can contribute to compensate this kind of adverse effects should be investigated in future research. It is crucial to systematically analyze which product categories would benefit most from empowerment ads. As also discussed in Sect. 1, other sustainable product categories might be associated with a financial benefit (e.g., Bobeth and Matthies 2018), thus, the interaction effects of product price and ad type should be also considered in future. In addition, consumers' choices might be more driven by individual preferences such as taste when considering food products (Rana and Paul 2017). It would be valuable to 
find out how empowerment ads affect consumers' responses where these factors play a minor role such as for commodity good, e.g., printing paper or other office supplies.

As outlined previously, a green empowerment ad contains a cost-intensive promise (investments in environment-friendly production) and might be primarily associated with a high-resource company. The high performance of combining an empowerment ad with resource information could be caused by a perceived fit of messages (e.g., messagecongruency; Kuipers and La Heij 2008). Future research should test whether message congruency drives the effects of company resources on advertisement effectiveness to better understand the underlying psychological mechanisms and apply them in different contexts.

\section{Appendix}

See Tables 8, 9 and Figs. 3,4.

Table 8 Stimuli (Studies 1 and 2)

\begin{tabular}{|c|c|}
\hline Group & Advertisement \\
\hline \multicolumn{2}{|l|}{ Ad type } \\
\hline Green empowerment & $\begin{array}{l}\text { "Use your power to move green production: By buying } \\
\text { environment-friendly products, you can send a signal that } \\
\text { you require us to offer more green products and to inten- } \\
\text { sify environment-friendly operations. Every consumer can } \\
\text { actively exercise buying power to influence the supplier } \\
\text { and therefore the environment." }\end{array}$ \\
\hline Non-green empowerment (only Study 2) & $\begin{array}{l}\text { "Use your power to move production: By making product } \\
\text { choices, you can send a signal that you require us to offer } \\
\text { more of the chosen products and to intensify related opera- } \\
\text { tions. Every consumer can actively exercise buying power } \\
\text { to influence the supplier." }\end{array}$ \\
\hline Green appeal & $\begin{array}{l}\text { "Help improve the environment: By buying environment- } \\
\text { friendly products, you can make a step forward to reduce } \\
\text { pollutants and to improve environmental quality. Every } \\
\text { consumer can take care of the environment." }\end{array}$ \\
\hline Control & "The product information comes from the platform." \\
\hline \multicolumn{2}{|l|}{ Corporate resources (only Study 2) } \\
\hline High corporate resources & $\begin{array}{l}\text { "Our company reached an annual turnover of } 91.4 \text { billion } \\
\text { Yuan in } 2018 \text {. We employ over } 323,000 \text { people in total. } \\
\text { We apply highly innovative technologies in our manufac- } \\
\text { turing and deliver high-end products to our customers." }\end{array}$ \\
\hline Low corporate resources & $\begin{array}{l}\text { "Our company reached an annual turnover of } 914,000 \text { Yuan } \\
\text { in } 2018 \text {. We employ over } 30 \text { people in total. We apply } \\
\text { manufacturing technologies of long traditions and deliver } \\
\text { high-quality products to our customers." }\end{array}$ \\
\hline Control & "This is the end of the page." \\
\hline
\end{tabular}

Messages shown were translated into Mandarin Chinese 


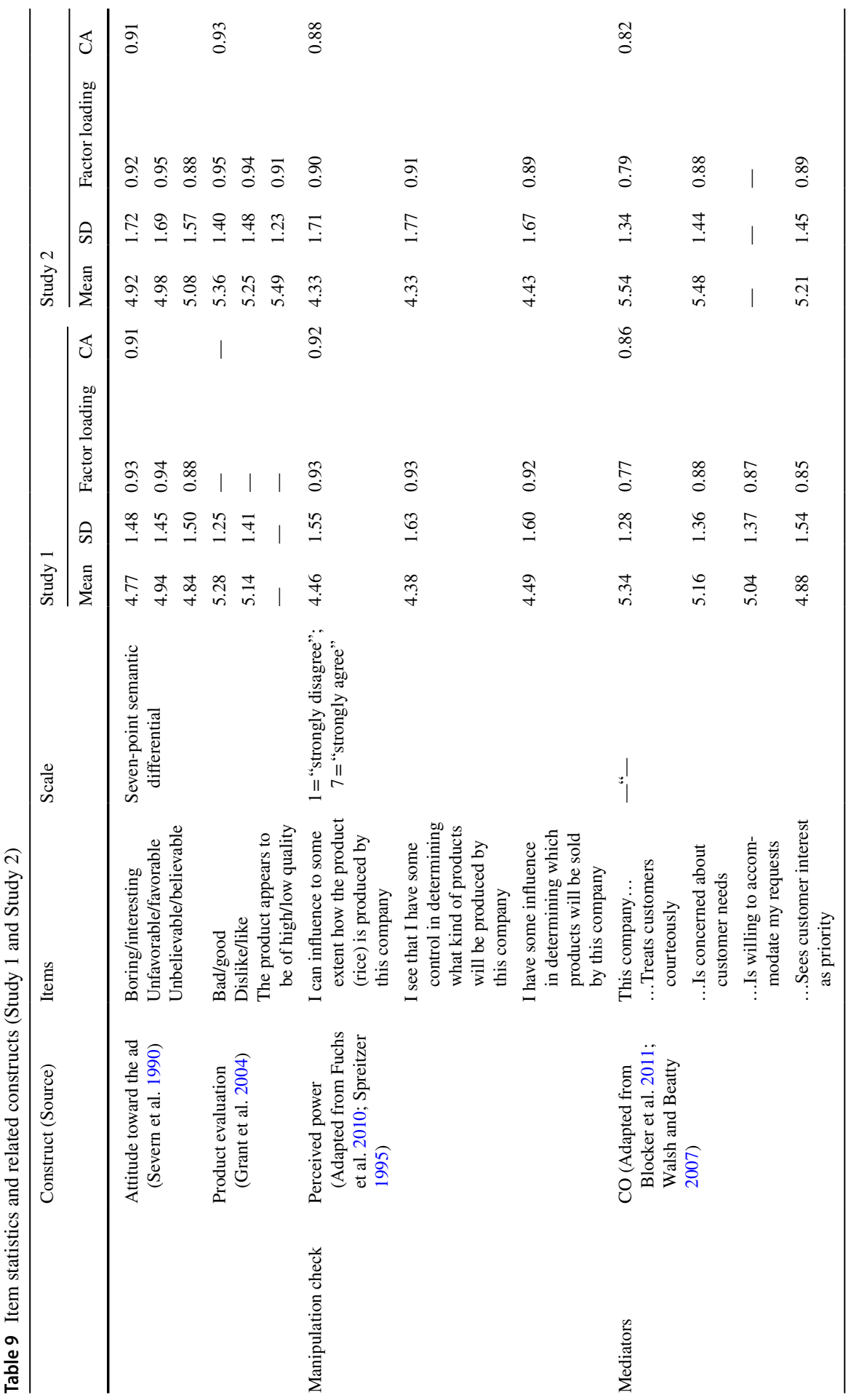




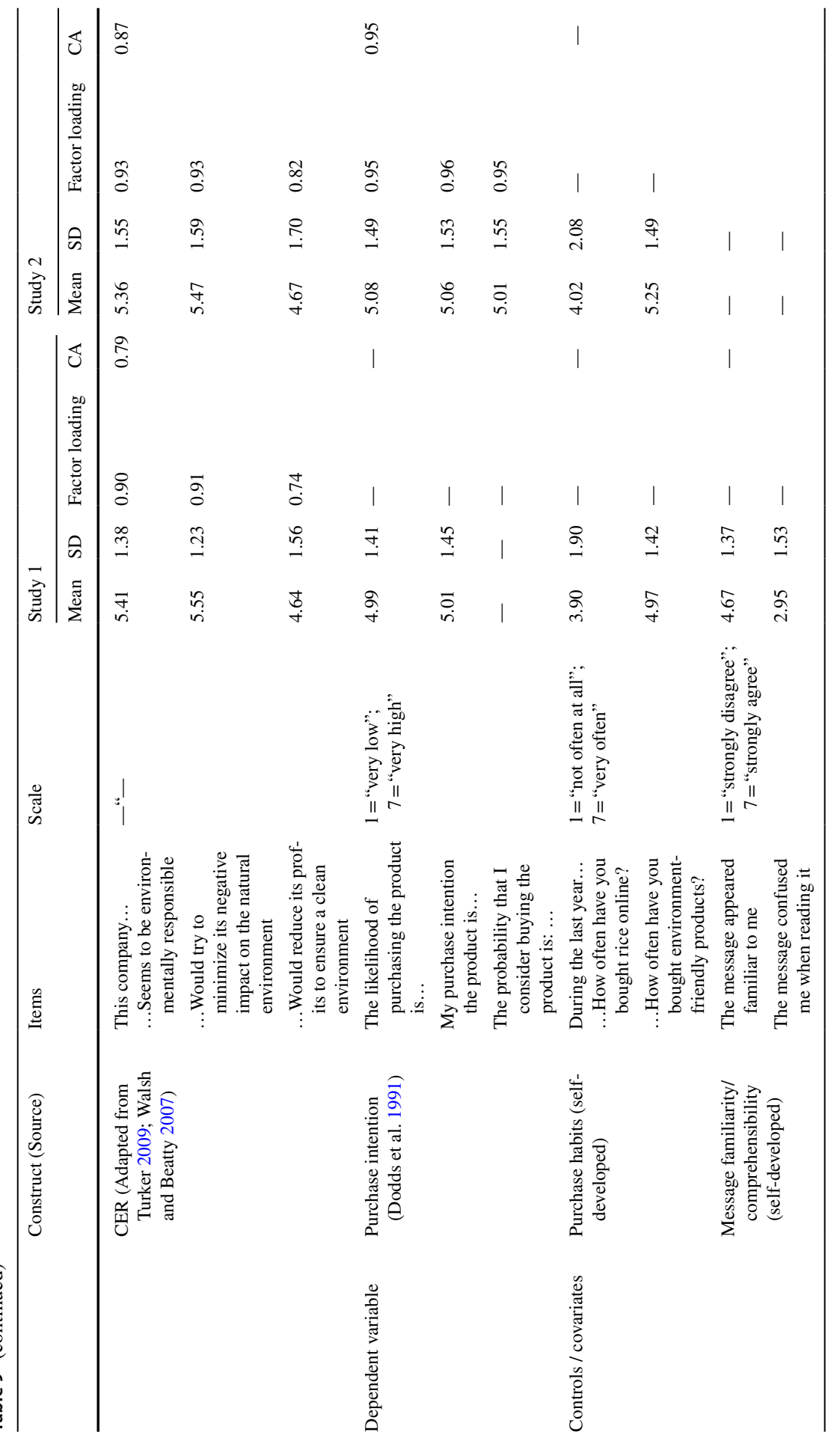




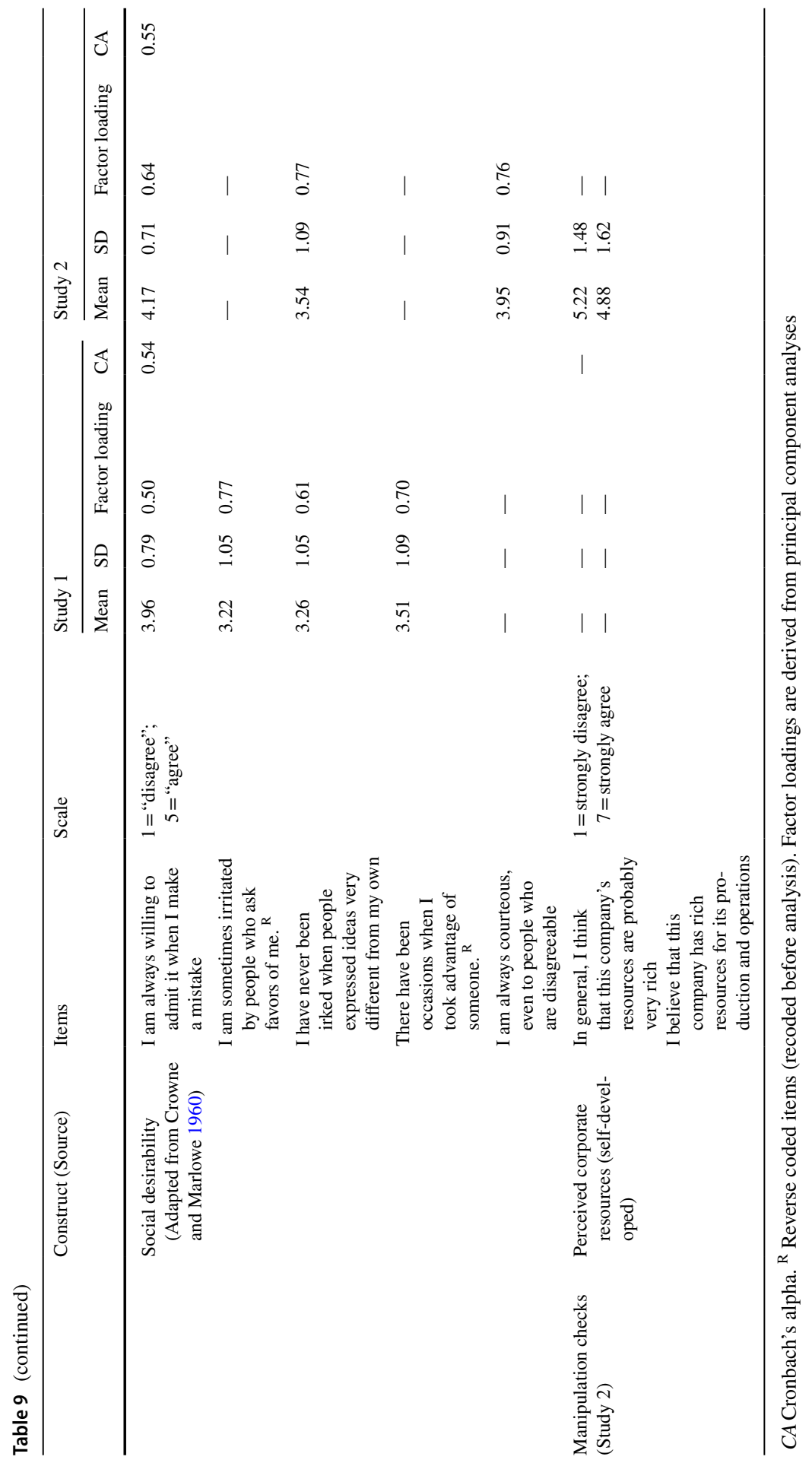


(a) Customer orientation

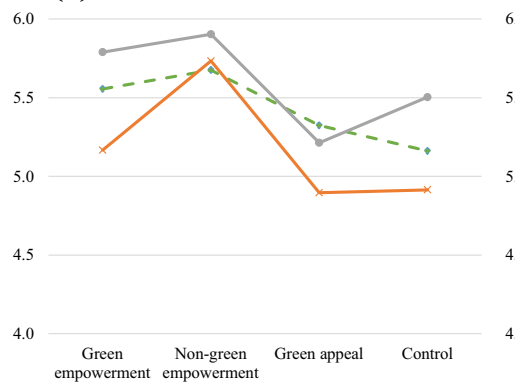

(b) Purchase intention

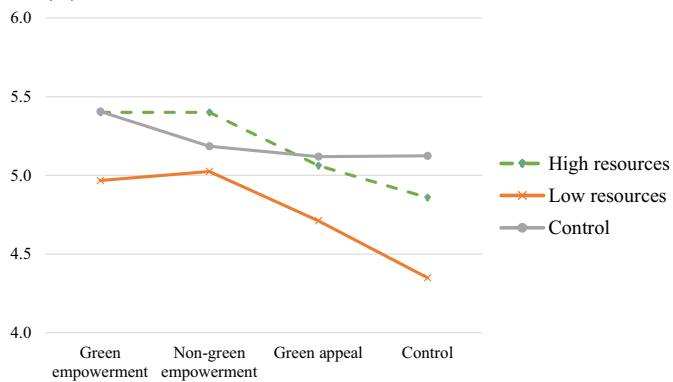

Fig. 3 Group means for CO and purchase intention (Study 2)

\section{Henglry for More?}

\section{Use your shopping dollar to vote for a fair food system \\ "We all have the power to change the world, three times a day in fact. Use your shopping dollar to vote for a fair food system, one that nourishes the earth, protects its animals, values its farmers and engages communities. One that will keep us full for generations to come. You hold that power in your hip pocket."}

Hayley Morris, Sustainable Table Co-Founder

Fig. 4 Example for consumer empowerment (CoM 2019)

Funding Open Access funding enabled and organized by Projekt DEAL. This research was financially supported by Akademische Marketinggesellschaft e.V., Leipzig, Germany.

Availability of data and material The data can be requested from the corresponding author.

Code availability Not applicable.

\section{Declarations}

Conflict of interest The authors state that there was no conflict of interest or competing interests at any time.

Open Access This article is licensed under a Creative Commons Attribution 4.0 International License, which permits use, sharing, adaptation, distribution and reproduction in any medium or format, as long as you give appropriate credit to the original author(s) and the source, provide a link to the Creative Commons licence, and indicate if changes were made. The images or other third party material in this article are included in the article's Creative Commons licence, unless indicated otherwise in a credit line to the material. If material is not included in the article's Creative Commons licence and your intended use is not permitted by statutory regulation or exceeds the permitted use, you will need to obtain permission directly from the copyright holder. To view a copy of this licence, visit http://creativecommons.org/licen ses/by/4.0/. 


\section{References}

Auger P, Devinney TM, Louviere JJ, Burke PF (2008) Do social product features have value to consumers? Int J Res Mark 25(3):183-191. https://doi.org/10.1016/j.ijresmar.2008.03.005

Akhavannasab S, Dantas DC, Senecal S (2018) Consumer empowerment in consumer-firm relationships: conceptual framework and implications for research. AMS Rev 8:214-227. https://doi.org/10.1007/ s13162-018-0120-4

Ali R, Lynch R, Melewar TC, Jin Z (2015) The moderating influences on the relationship of corporate reputation with its antecedents and consequences: a meta-analytic review. J Bus Res 68:11051117. https://doi.org/10.1016/j.jbusres.2014.10.013

Álvarez-Gil MJ, Berrone P, Husillos FJ, Lado N (2007) Reverse logistics, stakeholders' influence, organizational slack, and managers' posture. J Bus Res 60:463-473. https://doi.org/10.1016/j.jbusres. 2006.12.004

Amatulli C, de Angelis M, Peluso AM, Soscia I, Guido G (2019) The effect of negative message framing on green consumption: an investigation of the role of shame. J Bus Ethics 157:1111-1132. https:// doi.org/10.1007/s10551-017-3644-x

Anderson C, Galinsky AD (2006) Power, optimism, and risk-taking. Eur J Soc Psychol 36:511-536. https://doi.org/10.1002/ejsp.324

Atkinson L, Rosenthal S (2014) Signaling the green sell: the influence of eco-label source, argument specificity, and product involvement on consumer trust. J Advert 43:33-45. https://doi.org/10.1080/ 00913367.2013.834803

Bianchi E, Bruno JM, Sarabia-Sanchez FJ (2019) The impact of perceived CSR on corporate reputation and intention to buy sustainable food. EJMBE 28:206-221. https://doi.org/10.1108/ EJMBE-12-2017-0068

Blocker CP, Flint DJ, Myers MB, Slater SF (2011) Proactive customer orientation and its role for creating customer value in global markets. J Acad Mark Sci 39:216-233. https://doi.org/10.1007/ s11747-010-0202-9

Bobeth S, Matthies E (2018) New opportunities for electric car adoption: the case of range myths, new forms of subsidies, and social norms. Energ Eff 11(7):1763-1782

Brady MK, Cronin JJ (2001) Customer orientation: effects on customer service perceptions and outcome behaviors. J Serv Res 3:241-251. https://doi.org/10.1177/109467050133005

Buerke A, Straatmann T, Lin-Hi N, Müller K (2017) Consumer awareness and sustainability-focused value orientation as motivating factors of responsible consumer behavior. Rev Manag Sci 11:959-991. https://doi.org/10.1007/s11846-016-0211-2

Burke RR (1997) Do you see what I see? The future of virtual shopping. J Acad Mark Sci 25:352-360

Bügel MS, Verhoef PC, Buunk AP (2011) Customer intimacy and commitment to relationships with firms in five different sectors: preliminary evidence. J Retail Consum Servi 18:247-258. https:// doi.org/10.1016/j.jretconser.2010.11.005

Chang H, Zhang L, Xie G-X (2015) Message framing in green advertising: the effect of construal level and consumer environmental concern. Int J Advert 34:158-176. https://doi.org/10.1080/ 02650487.2014.994731

Cheng Z-H, Chang C-T, Lee Y-K (2020) Linking hedonic and utilitarian shopping values to consumer skepticism and green consumption: the roles of environmental involvement and locus of control. Rev Manag Sci 14:61-85. https://doi.org/10.1007/s11846-018-0286-z

Carrington MJ, Neville BA, Whitwell GJ (2014) Lost in translation: exploring the ethical consumer intention-behavior gap. J Bus Res 67(1):2759-2767. https://doi.org/10.1016/j.jbusres.2012.09. 022

City of Melbourne (CoM) (2019) We need to talk about food. https://sustainabletable.org.au/wp-content/ uploads/We-need-to-talk-about-food.pdf Accessed August 282021

CNN (2010) Greenpeace, Nestlé in battle over Kit Kat viral. http://edition.cnn.com/2010/WORLD/asiap cf/03/19/indonesia.rainforests.orangutan.nestle/index.html Accessed August 282021

Crowne DP, Marlowe D (1960) A new scale of social desirability independent of psychopathology. J Consult Psychol 24:349-354. https://doi.org/10.1037/h0047358

Del Brìo JA, Junquera B (2003) A review of the literature on environmental innovation management in SMEs: implications for public policies. Technovation 23:939-948. https://doi.org/10.1016/ S0166-4972(02)00036-6 
Denegri-Knott J, Zwick D, Schroeder JE (2006) Mapping consumer power: an integrative framework for marketing and consumer research. Eur J Mark 40(9/10):950-971. https://doi.org/10.1108/ 03090560610680952

Deshpandé R, Farley JU, Webster FE (1999) Corporate culture, customer orientation, and innovativeness in Japanese firms: a quadrad analysis. J Mark 57:23-37. https://doi.org/10.1177/00222 4299305700102

Desmeules R (2002) The impact of variety on consumer happiness: marketing and the tyranny of freedom. Acad of Mark Sci Rev 12(1):1-18

Diamantopoulos A, Sarstedt M, Fuchs C, Wilczynski P, Kaiser S (2012) Guidelines for choosing between multi-item and single-item scales for construct measurement: a predictive validity perspective. J Acad Mark Sci 40:434-449. https://doi.org/10.1007/s11747-011-0300-3

Dodds WB, Monroe KB, Grewal D (1991) Effects of price, brand, and store information on buyers' product evaluations. J Mark Res 28:307-319. https://doi.org/10.2307/3172866

Douglas SP, Craig CS (2007) Collaborative and iterative translation: an alternative approach to back translation. J Int Mark 15:30-43. https://doi.org/10.1509/jimk.15.1.030

Ersche KD, Lim TV, Ward LH, Robbins TW, Stochl J (2017) Creature of habit: a self-report measure of habitual routines and automatic tendencies in everyday life. Pers Ind Differ 116:73-85. https://doi.org/10.1016/j.paid.2017.04.024

Etzion D (2007) Research on organizations and the natural environment, 1992-present: a review. J Man 33: 637-664. https://doi.org/10.1177/2F0149206307302553

EU (2019) Agricultural Markets Briefs No 13 | March 2019 Organic farming in the EU https://ec. europa.eu/info/sites/info/files/food-farming-fisheries/farming/documents/market-brief-organicfarming-in-the-eu_mar2019_en.pdf. Accessed March 182021

Fuchs C, Schreier M (2010) Customer empowerment in new product development. J Prod Innov Manage 28:17-32. https://doi.org/10.1111/j.1540-5885.2010.00778.x

Fuchs C, Prandelli E, Schreier M (2010) The psychological effects of empowerment strategies on consumers' product demand. J Mark 74:65-79. https://doi.org/10.1509/jmkg.74.1.65

Füller J, Mühlbacher H, Matzler K, Jawecki G (2009) Consumer empowerment through internet-based co-creation. J Man Inf Syst 26:71-102. https://doi.org/10.2753/MIS0742-1222260303

Galarraga I, Markandya A (2004) Economic techniques to estimate the demand for sustainable products: a case study for fair trade and organic coffee in the United Kingdom. Econ Agrar y Recurs Nat 4(1380-2016-115379): 109-134. https://doi.org/10.22004/ag.econ.28732

Galinsky AD, Gruenfeld DH, Magee JC (2003) From power to action. J Pers Soc Psychol 85:453-466. https://doi.org/10.1037/0022-3514.85.3.453

Gomiero T, Pimentel D, Paoletti MG (2011) Environmental impact of different agricultural management practices: conventional vs. organic agriculture. Crit Rev Plant Sci 30(1-2): 95-124. https://doi.org/10.1080/07352689.2011.554355

Glavas A, Kelley K (2014) The effects of perceived corporate social responsibility on employee attitudes. Bus Ethics Q

González-Benito J, González-Benito Ó (2006) A review of determinant factors of environmental proactivity. Bus Str Environ 15:87-102. https://doi.org/10.1002/bse.450

Grant SJ, Malaviya P, Sternthal B (2004) The influence of negation on product evaluations. J Consum Res 31:583-591. https://doi.org/10.1086/425093

Grimmer M, Bingham T (2013) Company environmental performance and consumer intention to buy sustainable foods. J B Res 66:1945-1953. https://doi.org/10.1016/j.jbusres.2013.02.017

Grimmer M, Woolley M (2014) Green marketing messages and consumers' intention to buy sustainable foods: Promoting personal versus environmental benefits. J Mark Commun 20:231-250. https://doi.org/10.1080/13527266.2012.684065

Haase FV, Kohlmeyer M, Rich B, Woll R (2016) Determination of additional willingness to pay for socially responsible technical products using discrete choice analysis. J Manag Sustain Can Center Sci Edu 6(1):45-58. https://doi.org/10.5539/jms.v6nlp45

Ham CD, Kim J (2020) The effects of CSR communication in corporate crises: examining the role of dispositional and situational CSR skepticism in context. Publ Rel Rev 46:101792. https://doi.org/ 10.1016/j.pubrev.2019.05.013

Hayes AF (2018) Introduction to mediation, moderation, and conditional process analysis: A regressionbased approach, Second edition. Methodology in the social sciences. The Guilford Press, New York, London 
Hofenk D, van Birgelen M, Bloemer J, Semeijn J (2019) How and when retailers' sustainability efforts translate into positive consumer responses: the interplay between personal and social factors. J Bus Ethics 156:473-492. https://doi.org/10.1007/s10551-017-3616-1

Howie KM, Yang L, Vitell SJ, Bush V, Vorhies D (2018) Consumer participation in cause-related marketing: an examination of effort demands and defensive denial. J Bus Ethics 147:679-692. https:// doi.org/10.1007/s10551-015-2961-1

Isenhour C (2010) On conflicted Swedish consumers, the effort to stop shopping and neoliberal environmental governance. J Cons Behav 9:454-469. https://doi.org/10.1002/cb.336

Ivanova D, Stadler K, Steen-Olsen K, Wood R, Vita G, Tukker A, Hertwich EG (2016) Environmental impact assessment of household consumption. J Ind Ecol 20:526-536. https://doi.org/10.1111/jiec. 12371

Jacobsen LF, Tudoran AA, Martinez MG (2020) Examining trust in consumers as new food co-creators: Does the communicator matter? Food Qual Prefect 86:104004. https://doi.org/10.1016/j.foodqual. 2020.104004

Jäger AK, Weber A (2020) Can you believe it? The effects of benefit type versus construal level on advertisement credibility and intention to buy sustainable food for organic food. J Clean Prod 257:120543. https://doi.org/10.1016/j.jclepro.2020.120543

Jeyaraj A, Rottman JW, Lacity MC (2006) A review of the predictors, linkages, and biases in IT innovation adoption research. J Inf Tech 21:1-23

Jiménez M, Yang KCC (2010) How guilt level affects green advertising effectiveness? J Creat Commun 3:231-254. https://doi.org/10.1177/097325861000300301

Kareklas I, Carlson JR, Muehling DD (2014) "I eat organic for my benefit and yours": egoistic and altruistic considerations for purchasing organic food and their implications for advertising strategists. J Advert 43:18-32. https://doi.org/10.1080/00913367.2013.799450

Keltner D, Gruenfeld DH, Anderson C (2003) Power, approach, and inhibition. Psychol Rev 110:265284. https://doi.org/10.1037/0033-295X.110.2.265

Klonsky K (2012) Comparison of production costs and resource use for organic and conventional production systems. Am J Agri Econ 94:314-321

Kotler P (2011) Reinventing marketing to manage the environmental imperative. J Mark, 75: 132-135. https://doi.org/10.1509/2Fjmkg.75.4.132

Lenzen M, Murray J, Sack F, Wiedmann T (2007) Shared producer and consumer responsibility-theory and practice. Ecol Econ 61:27-42. https://doi.org/10.1016/j.ecolecon.2006.05.018

Lin CY, Ho YH (2011) Determinants of green practice adoption for logistics companies in China. J Bus Ethics 98:67-83. https://doi.org/10.1007/s10551-010-0535-9

Lincoln ND, Travers C, Ackers P, Wilkinson A (2002) The meaning of empowerment: The interdisciplinary etymology of a new management concept. Int J Man Rev 4:271-290. https://doi.org/10.1111/ $1468-2370.00087$

Loo R, Loewen P (2004) Confirmatory factor analyses of scores from full and short versions of the marlowe-crowne social desirability scale. J Appl Soc Pyschol 34:2343-2352. https://doi.org/10. 1111/j.1559-1816.2004.tb01980.x

Luchs MG, Naylor RW, Irwin JR, Raghunathan R (2010) The sustainability liability: potential negative effects of ethicality on product preference. J Mark 74:18-31. https://doi.org/10.1509/jmkg.74.5.018

Lu Y, Abeysekera I, Cortese C (2015) Corporate social responsibility reporting quality, board characteristics and corporate social reputation: Evidence from China. Pacific Account Rev 27:95-118. https:// doi.org/10.1108/PAR-10-2012-0053

Ma Y, Liu ZH, Xi BD, He XS, Li Q, Qi YJ et al (2019) Characteristics of groundwater pollution in a vegetable cultivation area of typical facility agriculture in a developed city. Ecol Ind 105:709-716. https://doi.org/10.1016/j.ecolind.2018.10.056

McDonald S, Oates C, Thyne M, Alevizou P, McMorland L-A (2009) Comparing sustainable consumption patterns across product sectors. Int J Consum Stud 33:137-145. https://doi.org/10.1111/j. 1470-6431.2009.00755.x

Mohr LA, Webb DJ, Harris KE (2001) Do consumers expect companies to be socially responsible? The Impact of corporate social responsibility on buying behavior. J Consum Aff 35:45-72. https://doi. org/10.1111/j.1745-6606.2001.tb00102.x

Montgomery C, Stone G (2009) Revisiting consumer environmental responsibility: a five nation crosscultural analysis and comparison of consumer ecological opinions and behaviors. Int J Man Mark Res 2:35-58 
Newman GE, Gorlin M, Dhar R (2014) When going green backfires: how firm intentions shape the evaluation of socially beneficial product enhancements. J Consum Res 41:823-839. https://doi.org/10. $1086 / 677841$

Nilssen R, Bick G, Abratt R (2019) Comparing the relative importance of sustainability as a consumer purchase criterion of food and clothing in the retail sector. J Brand Manag 26:71-83. https://doi. org/10.1057/s41262-018-0113-5

Nkwocha I, Bao Y, Johnson WC, Brotspies HV (2005) Product fit and consumer attitude toward brand extensions: the moderating role of product involvement. J Mark Theo and Pract 13:49-61. https:// doi.org/10.1080/10696679.2005.11658549

Nyilasy G, Gangadharbatla H, Paladino A (2014) Perceived greenwashing: the interactive effects of green advertising and corporate environmental performance on consumer reactions. J Bus Ethics 125:693-707. https://doi.org/10.1007/s10551-013-1944-3

Paas LJ, Dolnicar S, Karlsson L (2018) Instructional manipulation checks: a longitudinal analysis with implications for MTurk. Int J Res Mark 35:258-269. https://doi.org/10.1016/j.ijresmar.2018.01.003

Park H, Reber BH (2008) Relationship building and the use of web sites: How Fortune 500 corporations use their web sites to build relationships. Public Relat Rev 34:409-411. https://doi.org/10.1016/j. pubrev.2008.06.006

Petrescu M (2013) Marketing research using single-item indicators in structural equation models. J Mark Anal 1:99-117

Pierce JL, Kostova T, Dirks KT (2003) The State of psychological ownership: integrating and extending a century of research. Rev Gen Psychol 7:84-107. https://doi.org/10.1037/1089-2680.7.1.84

Poore J, Nemecek T (2018) Reducing food's environmental impacts through producers and con-sumers. Sci 360:987-992. https://doi.org/10.1126/science.aaq0216

Prada M, Garrido MV, Rodrigues D (2017) Lost in processing? Perceived healthfulness, taste and caloric content of whole and processed organic food. Appetite 114:175-186. https://doi.org/10.1016/j. appet.2017.03.031

Ramirez E, Jiménez FR, Gau R (2015) Concrete and abstract goals associated with the consumption of environmentally sustainable products. Eur J Mark 49:1645-1665. https://doi.org/10.1108/ EJM-08-2012-0483

Rana J, Paul J (2017) Consumer behavior and purchase intention for organic food: a review and research agenda. J Retail and Cons Serv 38:157-165. https://doi.org/10.1016/j.jretconser.2017.06.004

Rezabakhsh B, Bornemann D, Hansen U, Schrader U (2006) Consumer power: a comparison of the old economy and the Internet economy. J Consum Policy 29:3-36. https://doi.org/10.1007/ s10603-005-3307-7

Rucker DD, Galinsky AD, Dubois D (2012) Power and consumer behavior: how power shapes who and what consumers value. J Consum Psychol 22:352-368. https://doi.org/10.1016/j.jcps.2011.06.001

Ruth JA, York A (2004) Framing information to enhance corporate reputation: the impact of message source, information type, and reference point. J Bus Res 57:14-20. https://doi.org/10.1016/S01482963(02)00270-9

Sarstedt M, Wilczynski P (2009) More for less? A comparison of single-item and multi-item measures. DBW 69:211-227

Schwartz SH (2007) Cultural and individual value correlates of capitalism: a comparative analysis. Psychol Inq 18:52-57. https://doi.org/10.1080/10478400701388963

Seroka-Stolka O, Fijorek K (2020) Enhancing corporate sustainable development: Proactive environmental strategy, stakeholder pressure and the moderating effect of firm size. Bus Strat Env 29:23382354. https://doi.org/10.1002/bse.2506

Severn J, Belch GE, Belch MA (1990) The effects of sexual and non-sexual advertising appeals and information level on cognitive processing and communication effectiveness. J Advert 19:14-22. https:// doi.org/10.1080/00913367.1990.10673176

Shaw D, Newholm T, Dickinson R (2006) Consumption as voting: an exploration of consumer empowerment. Eur J Mark 40:1049-1067. https://doi.org/10.1108/03090560610681005

Spencer-Oatey H (1997) Unequal relationships in high and low power distance societies: a comparative study of tutor-student role relations in Britain and China. J Cross Cult Psychol 28:284-302. https:// doi.org/10.1177/0022022197283005

Spreitzer GM (1995) An empirical test of a comprehensive model of intrapersonal empowerment in the workplace. Am J Commun Psychol 23:601-629. https://doi.org/10.1007/BF02506984

Sudbury-Riley L, Kohlbacher F (2016) Ethically minded consumer behavior: scale review, development, and validation. J Bus Res 69:2697-2710. https://doi.org/10.1016/j.jbusres.2015.11.005 
Tashi S, Wangchuk K (2016) Organic vs. conventional rice production: comparative assessment under farmers' condition in Bhutan. Org Agric 6:255-265. https://doi.org/10.1007/s13165-015-0132-4

Thøgersen J, Jørgensen AK, Sandager S (2012) Consumer decision making regarding a "green" everyday product. Psychol Mark 29:187-197. https://doi.org/10.1002/mar.20514

Thøgersen J, Zhou Y (2012) Chinese consumers' adoption of a 'green' innovation-the case of organic food. J Mark Manag 28:313-333. https://doi.org/10.1080/0267257X.2012.658834

Tully SM, Winer RS (2014) The role of the beneficiary in willingness to pay for socially responsible products: a meta-analysis. J Retail 90(2):255-274. https://doi.org/10.1016/j.jretai.2014.03.004

Turker D (2009) Measuring corporate social responsibility: a scale development study. J Bus Ethics 85:411-427. https://doi.org/10.1007/s10551-008-9780-6

van Doorn J, Onrust M, Verhoef PC, Bügel MS (2017) The impact of corporate social responsibility on customer attitudes and retention-the moderating role of brand success indicators. Mark Lett 28:607-619. https://doi.org/10.1007/s11002-017-9433-6

Van Ewijk BJ, Steenkamp JBE, Gijsbrechts E (2020) The Rise of Online Grocery Shopping in China: Which Brands Will Benefit? J Int Mark 28:20-39. https://doi.org/10.1177/1069031X20914265

Walsh G, Beatty SE (2007) Customer-based corporate reputation of a service firm: Scale development and validation. J Acad Mark Sci 35:127-143. https://doi.org/10.1007/s11747-007-0015-7

Willer H, Schlatter B, Trávníek J, Kemper K, Lernoud J. (2020) The World of organic agriculture. Statistics and emerging trends 2020. Research Institute of Organic Agriculture (FiBL). http://www.organ ic-world.net/yearbook/yearbook-2020.html.. Accessed 18 March 2021

White K, Macdonnell R, Dahl DW (2011) It's the mind-set that matters: the role of construal level and message framing in influencing consumer efficacy and conservation behaviors. J Mark Res 48:472-485. https://doi.org/10.1509/jmkr.48.3.472

Wong WY, Lai KH, Shang KC, Lu CS (2014) Uncovering the value of green advertising for environmental management practices. Bus Strat Env 23:117-130. https://doi.org/10.1002/bse.1776

Wright LT, Shankar A, Cherrier H, Canniford R (2006) Consumer empowerment: a Foucauldian interpretation. Eur J Mark.

Wu G-C (2017) Effects of socially responsible supplier development and sustainability-oriented innovation on sustainable development: empirical evidence from SMEs. Corp Soc Responsib Environ Manag 24:661-675. https://doi.org/10.1002/csr.1435

Yang X, Weber A (2019) Who can improve the environment-Me or the powerful others? An integrative approach to locus of control and pro-environmental behavior in China. Resour Conserv Recycl 146:55-67. https://doi.org/10.1016/j.resconrec.2019.03.005

Zhao X, Lynch JG, Chen Q (2010) Reconsidering Baron and Kenny: myths and truths about mediation analysis. J Consum Res 37:197-206. https://doi.org/10.1086/651257

Zhou Y, Poon P, Huang G (2012) Corporate ability and corporate social responsibility in a developing country: the role of product involvement. J Glob Mark 25:45-56. https://doi.org/10.1080/08911 762.2012 .697385

Publisher's Note Springer Nature remains neutral with regard to jurisdictional claims in published maps and institutional affiliations. 